\title{
Competence and regulatory interactions during regeneration in plants
}

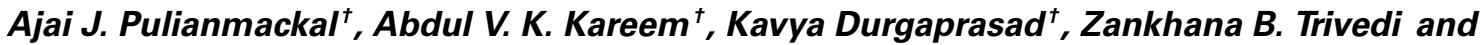 Kalika Prasad*}

School of Biology, Indian Institute of Science Education and Research, Thiruvananthapuram, India

Edited by:

Jian Xu, National University of

Singapore, Singapore

Reviewed by:

Rita Sharma, University of California,

Davis, USA

Xian Sheng Zhang, Shandong

Agricultural University, China

\section{*Correspondence:}

Kalika Prasad, School of Biology

Indian Institute of Science Education

and Research, Thiruvananthapuram,

India

e-mail: kalika@iisertvm.ac.in

${ }^{\dagger}$ These authors have contributed equally to this work.
The ability to regenerate is widely exploited by multitudes of organisms ranging from unicellular bacteria to multicellular plants for their propagation and repair. But the levels of competence for regeneration vary from species to species. While variety of living cells of a plant display regeneration ability, only a few set of cells maintain their stemness in mammals. This highly pliable nature of plant cells in-terms of regeneration can be attributed to their high developmental plasticity. De novo organ initiation can be relatively easily achieved in plants by proper hormonal regulations. Elevated levels of plant hormone auxin induces the formation of proliferating mass of pluripotent cells called callus, which predominantly express lateral root meristem markers and hence is having an identity similar to lateral root primordia. Organ formation can be induced from the callus by modulating the ratio of hormones. An alternative for de novo organogenesis is by the forced expression of plant specific transcription factors. The mechanisms by which plant cells attain competence for regeneration on hormonal treatment or forced expression remain largely elusive. Recent studies have provided some insight into how the epigenetic modifications in plants affect this competence. In this review we discuss the present understanding of regenerative biology in plants and scrutinize the future prospectives of this topic. While discussing about the regeneration in the sporophyte of angiosperms which is well studied, here we outline the regenerative biology of the gametophytic phase and discuss about various strategies of regeneration that have evolved in the domain of life so that a common consensus on the entire process of regeneration can be made.

Keywords: competence for regeneration, De novo organ initiation, callus, epigenetic modifications, auxin, cytokinin

\section{INTRODUCTION}

Throughout their lifecycle, plants and animals are subjected to various physical assaults like injury, diseases, or attack by predators. Both these kingdoms deploy the process of regeneration to restore the damage accrued to their body parts as a result of regular wear and tear (Figure 1) (Birnbaum and Sanchez Alvarado, 2008; Sena and Birnbaum, 2010; Sugimoto et al., 2011). Regeneration is highly pronounced in plants compared to animals since they are more prone to abrasion due to their sessile nature (Legendre and Gautheret, 2003). Remarkable regenerative ability is also shown by a wide range of animals. The regeneration of amputated limb by salamanders (Brockes and Kumar, 2002) is the most cited example of regeneration in animals. Hydra exhibits marvelous capability to regenerate the entire body plan by mere reaggregation of its dissociated cells (Gierer et al., 1972). In most cases, the regeneration in plants and animals proceeds via the formation of intermediate mass of highly specialized tissue with high regenerative capability called callus and blastema, respectively (Birnbaum and Sanchez Alvarado, 2008). Plants, besides possessing the capability to replace the lost organs, also display a striking ability to regenerate entirely new individuals from the damaged organs, a property unique to plants which was demonstrated in the leaves of begonias and pansies. The plant cells are widely believed to be totipotent as the differentiated cells of the plant possess the capability to give rise to a new plant on provision of suitable in vitro culture conditions (Skoog and Miller, 1957; Halperin, 1986). But, the regenerative potential of the cells within the same plant varies with the cell type and also with the different stages of development (Guzzo et al., 1994).

Among the plants, Arabidopsis thaliana is one of the most celebrated model systems, which has been extensively exploited for carrying out in vitro regeneration studies (Weigel and Glazebrook, 2002). The plant shows high ability to regenerate ablated organs. Laser ablated root and shoot meristem regenerates quickly without any external hormonal supply in in planta (Reinhardt et al., 2003; Xu et al., 2006). Similar ability is also shown by other parts of the plant like leaves, bark, cotyledon, and root tip (Pang et al., 2008; Sena et al., 2009; Zhang et al., 2011; Chen et al., 2013). Study of mutants that are defective in regenerating the lost parts gives insight on the molecular pathways involved in providing competence for in planta regeneration (Xu et al., 2006; Pang et al., 2008; Sena et al., 2009; Zhang et al., 2012; Chen et al., 2013). Various parts of the plant like root, hypocotyl, cotyledons, leaves, petals, etc., serve as sources of explant for in vitro regeneration experiments (Weigel and Glazebrook, 2002). The regenerative fate of the explant is determined by the ratio 


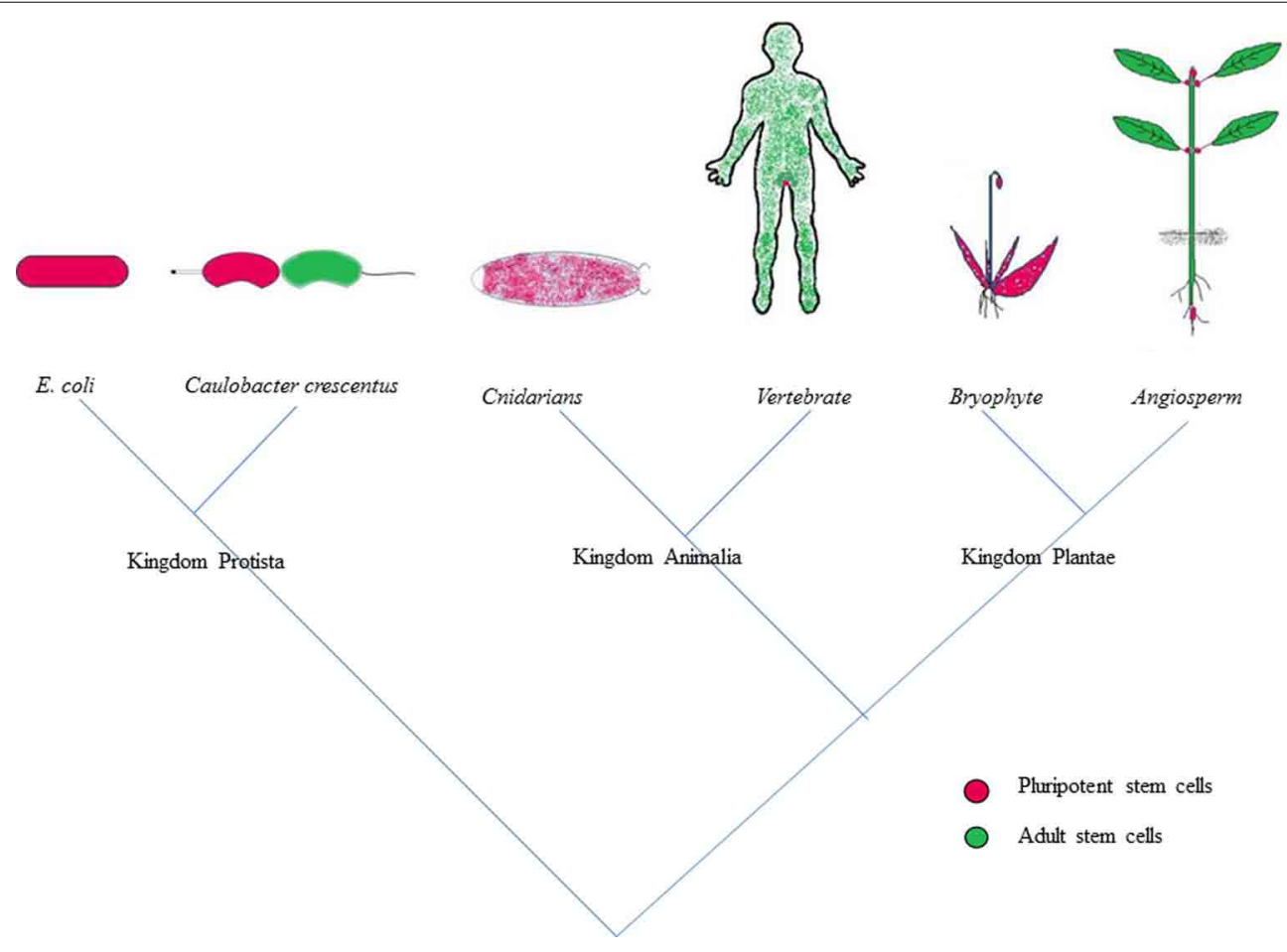

FIGURE 1 | Tree of regeneration; depicting the competence for regeneration across the kingdoms of life. Adult stem cells are partly differentiated cells that can give rise to a limited number of cell types while the pluripotent stem cells are competent to give rise to all lineages of cells. The pluripotent stem cells which play a major role in executing the regenerative duties in the lower organisms of each kingdom gave way to adult stem cells and occupy confined niches in higher organisms. between two important plant hormones, auxin, and cytokinin (Skoog and Miller, 1957). High auxin to cytokinin ratio destines root fate from the explant, while high cytokinin to auxin ratio specifies shoot regeneration. Regeneration from the explant can proceed either directly or indirectly. The direct mode of regeneration involves the development of either root or shoot directly from the explants (Atta et al., 2009) in contrast to the indirect mode, where an intervening step of callus formation precedes regeneration (Valvekens et al., 1988). Intriguingly, recent body of experiments has brought to lime light, the crucial role played by epigenetic modifications in regeneration (Xu and Huang, 2014).

Studies on various mutant combinations and several marker lines coupled with high resolution live imaging have been carried out to delineate the mechanism of de novo organogenesis in Arabidopsis (Gordon et al., 2007; Atta et al., 2009; Sugimoto et al., 2010; Chatfield et al., 2013; Motte et al., 2013). Yet many facts pertaining to regeneration like, how cells at the site of damage acquire the competence to regenerate the entire lost body part and what is the initial trigger for reprogramming during regeneration still remains elusive. Detailed aspects of regeneration, the key players involved in in vitro regeneration, possible mechanistic insights and the evolutionarily conserved aspects of regeneration across the plant kingdom will be addressed in this review (Figure 1).

\section{REGENERATION UPON WOUNDING}

The power to regenerate complex structures at the site of injury has been well celebrated in plants and animals. Limb regeneration in salamander (Godwin et al., 2013; Sandoval-Guzman et al., 2013), tail regeneration in Xenopus (Gargioli and Slack, 2004) and fin and heart regeneration in zebra fish (Jopling et al., 2010; Wang et al., 2013) are very good examples for organ regeneration after amputation in animals. Similarly, regeneration of root tip and leaf after excision in Arabidopsis (Xu et al., 2006; Sena et al., 2009) and shoot and bark regeneration (Reinhardt et al., 2003; Zhang et al., 2011; Chen et al., 2013) are well documented organ to organ regeneration in plants (Figure 2). The amazing ability of the cells at the injured region to acquire competence to recover precisely the excised part of organ is a long standing area of research for developmental biologists.

The shoot and root apical meristems are responsible for the indeterminate growth of a plant, therefore the maintenance of these apical meristems during a wound is quite essential for its indeterminate growth. The Arabidopsis root meristem exhibits high regenerative potential upon the excision of root tip or laser ablation of quiescent center, QC (Figure 3) (Xu et al., 2006; Sena et al., 2009). Followed by the laser ablation, the auxin distribution at the tip of root meristem gets disrupted which triggers regeneration (Xu et al., 2006). A shift in auxin response is established just after $3 \mathrm{~h}$ of QC ablation and a proximally shifted new auxin maxima is developed after $16 \mathrm{~h}$ of the ablation, subsequently leading to the respecification of new QC. Interestingly, the change in auxin response induces cell fate changes as evident by the expression of key cell fate regulator, PLETHORA (PLT) just after $6 \mathrm{~h}$ of ablation, i.e., $3 \mathrm{~h}$ after the shift in auxin response 


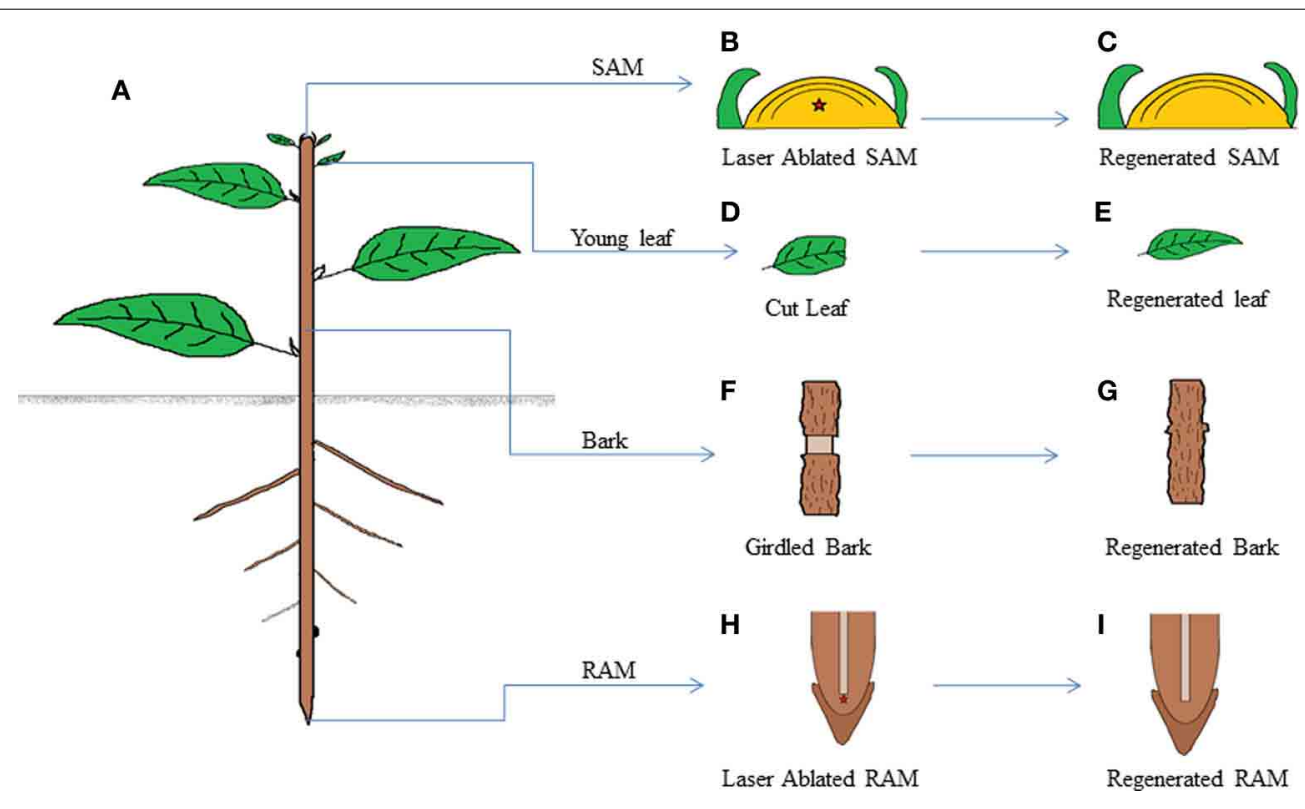

FIGURE 2 | Schematic drawing showing regeneration ability of various parts of a plant. A plant shows high levels of regeneration (A). When SAM of the plant is laser ablated, $(\mathbf{B})$ the wound gets regenerated without external hormonal application (C). Similarly various plant organs like young leaf (D,E), bark $(\mathbf{F}, \mathbf{G})$, and RAM $(\mathbf{H}, \mathbf{I})$ are able to regenerate the complete organ from the ablated organ without any extraneous hormonal application.
(Xu et al., 2006). PLT attains a new domain of expression and its activity triggers nuclear localization of SHORTROOT (SHR) in a single layer of provascular cells which in turn induces SCARECROW (SCR) expression. The new expression domain and activity of PLT, SCR, and SHR genes specify the new QC one or two cell layers above to the ablated QC within about $16 \mathrm{~h}$ of ablation. Thereafter the expression and polarization of polar auxin efflux carrier PINFORMED (PIN) are set facilitating the completion of regeneration (Xu et al., 2006).

Unlike the regeneration of QC after ablation, respecification of lost cell identity in the root meristem after root tip excision does not require maintenance of functional stem cell niche (Sena et al., 2009). While the mutants defective in stem cell maintenance like scr and plt1 plt2 double mutant are recalcitrant for QC regeneration ( $\mathrm{Xu}$ et al., 2006), the regeneration of cut root meristem does occur in these mutants (Sena et al., 2009). The regeneration of lost cell fate is initiated much before the morphological recovery of stem cell niche of root apical meristem in wild type Arabidopsis. This implies that although respecification of QC is an exclusive feature of functional stem cells, the competence for organ regeneration is not unique to stem cells. But it is also distributed among partially differentiated cells as the partially differentiated root meristematic cells retain the competence for organ regeneration.

It is clearly demonstrated that root tip regeneration after excision does not need the activity of PLT1 and PLT2 or its downstream targets (Sena et al., 2009). It is important to note that though plt1 plt 2 double mutant cannot maintain root stem cell niche (Aida et al., 2004), the residual stem cell activity retained during initial stages of growth of the seedling helps in the outgrowth of new roots. Necessity of other root PLTs such as PLT3 and PLT4 which can contribute toward residual stem cell activity in plt1 plt 2 mutant needs to be elucidated. It is possible that the complete removal of root stem cell activity may inhibit regeneration from cut root meristem. Early expression of stem cell markers like PLT genes during the regeneration of both root tip and QC is quite intriguing (Xu et al., 2006; Sena et al., 2009). It would be interesting to investigate whether the molecular recovery of stem cell regulators play a critical role for the initiation of the recovery of lost cell fate of the root tip.

Moving up from the root, bark is an important tissue that is prone to physical abrasions and hence the regeneration of bark is of prime importance for the survival of a plant. Significant progress has been made in understanding vascular tissue regeneration after bark girdling in tree species like Eucommia ulmoides and Populus tomentosa (Pang et al., 2008; Zhang et al., 2011; Chen et al., 2013). Tree plants are able to regenerate new bark and vasculature after wounding. Bark girdling removes phloem and cambium cells, but it leaves differentiating xylem (Zhang et al., 2011). The xylem cells exposed after wounding initiates regeneration by dedifferentiation and form proliferating mass of callus cells (Pang et al., 2008; Zhang et al., 2011). Wound cambium forms from the callus and gives rise to new phloem. Phellogen, which is derived from the wound callus initiates the formation of periderm, the outer layer of the bark, thereby completing the process of bark regeneration. Regeneration of new cell types from xylem cells does not require any external hormone application suggesting initial hormone surge would ramp up in response to wounding. Indeed, accumulating evidence point towards this notion. During the vascular tissue regeneration in Populus, the expression pattern of polar auxin transport genes is changed to establish auxin gradient for phloem and cambium recovery 


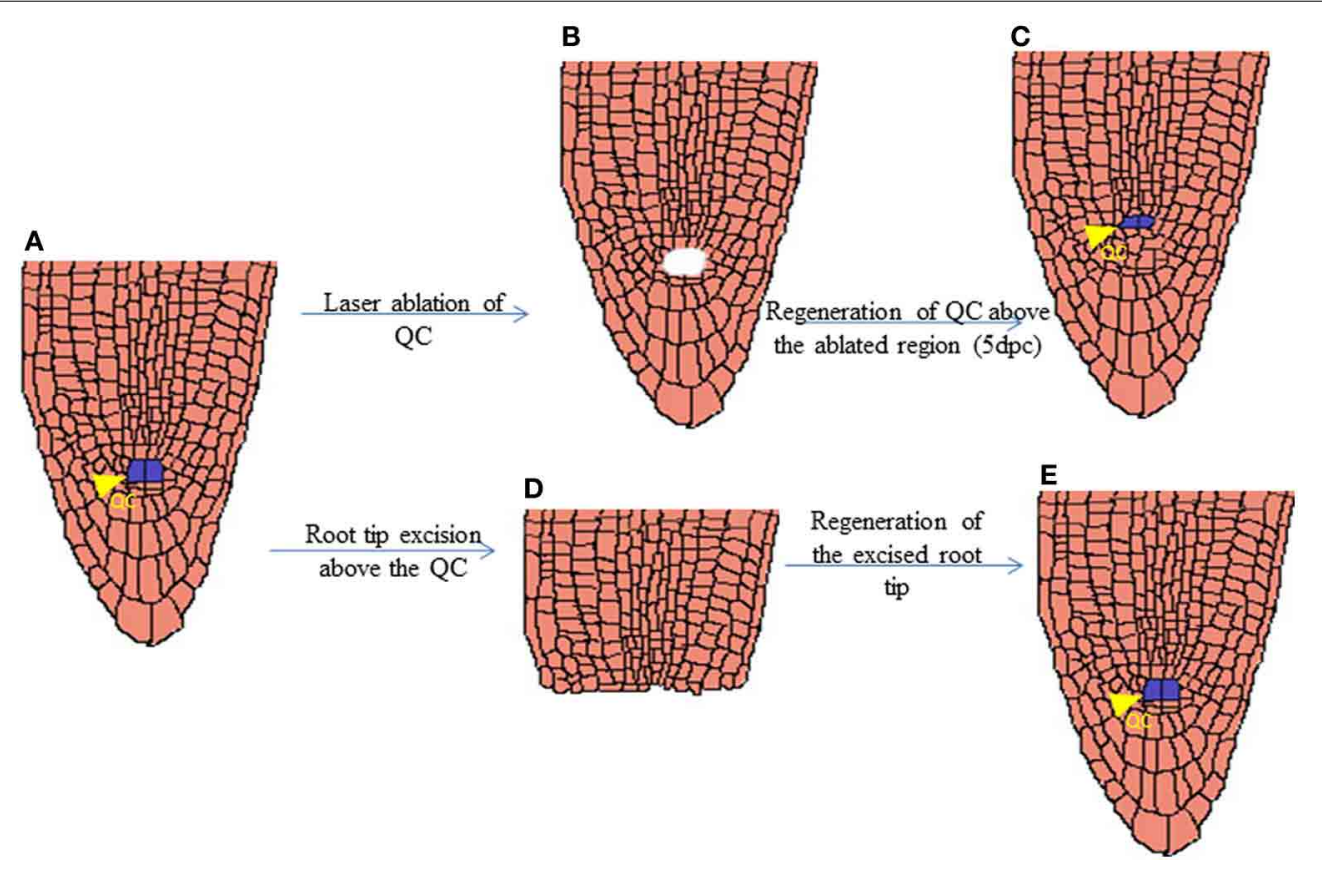

FIGURE 3 | Schematic representation of regenerated QC after laser ablation and root tip excision. Arabidopsis root tip with Quiescence cells (QC) marked in Blue (A). Root tip after Laser Ablation of QC cells (B).
Regenerated QC cells above the ablated region just 5 days post laser ablation (C). Excision of root tip above the QC region (D). Regenerated Root tip (E).
(Wang et al., 2009; Zhang et al., 2011). The regenerating cambium expresses the auxin influx carriers PttLAX2 and PttLAX3 and auxin efflux carrier PttPIN1 abundantly in Populus (Zhang et al., 2011). Xylem cells acquire competence to regenerate by epigenetic changes and cell cycle re-entry in Populus (Zhang et al., 2011). At the initial point of regeneration the xylem specific genes get downregulated while phloem and cambium specific genes are upregulated in the regenerating tissues (Zhang et al., 2011). The activation of phloem specific genes such as ALTERED PHLOEM DEVELOPMENT (APL), KANADI (KAN), and DNA binding with one finger (Dof) and cambium specific genes such as CLAVATA1 (CLV1), CLV2, AINTEGUMENTA1 (ANT1), SHR, and SCR promote the repatterning of hormone distribution in the regenerating tissues (Zhang et al., 2011). Simultaneously the cell signaling network is re-established to complete the process of vascular tissue regeneration.

Reinhardt et al. (2003) laser ablated the organizing center (OC) at the shoot apical meristem (SAM) of tomato, similar to the ablation of quiescent center of Arabidopsis root performed by Xu et al. (2006). The ablation of SAM however did not cause any significant patterning defects nor did affect the number of primordia that emerged from the meristem. As in root, the regeneration of meristem started immediately after the wounding of OC. The laser ablation of OC caused the complete disappearance of the meristem organizer LeWUS, tomato WUS homolog (Reinhardt et al., 2003). Ectopic expression of LeWUS as a ring around the ablated region is noticed within 1 day after the ablation. This is strikingly similar to the reappearance of WOX5 after laser ablation of QC in Arabidopsis root. The LeWUS levels accumulated to one locus, or in rare cases to two around the ablated region after 2 days reinstating the functional meristem expressing LeWUS (Reinhardt et al., 2003). Another striking feature of the laser ablation experiments conducted on the shoot meristem is the inability of cells at L1 layer of the shoot meristem to regenerate. When a few cells in L1 layer were laser ablated, they were unable to repair the wound (Reinhardt et al., 2003). This is quite different from the mode of regeneration seen in root where the incisions made on the root even above the QC are repairable (Sena et al., 2009).

What is the initial trigger for regeneration? It is a fundamental question asked by anyone working on regeneration. Auxin plays an instrumental role in the positioning of root stem cell niche (Aida et al., 2004; Cheng et al., 2013) and also in shoot and root organogenesis (Benkova et al., 2003). Auxin response is the earliest key determinant for the initiation of respecification of QC (Xu et al., 2006). The mutants defective in QC regeneration like scr, shr, and plt1 plt2 double mutant cannot maintain new auxin maxima after the laser ablation of QC suggesting cell fate specification occurs prior to high auxin response build up which in turn leads to completion of regeneration.

Importance of polar auxin transport is evident from the experiment where regeneration at root meristem failed to occur when the auxin transport was blocked by using N-1naphthylphthalamic acid (NPA) (Sena et al., 2009). Also, many genes were induced just after the excision of root tip in response to the aberrant levels of auxin (Sena et al., 2009). In light of these experiments, we reinforce the notion that the initial trigger for regeneration is the changes in auxin response. In shoot meristem, the levels of auxin and cytokinin are kept at a constant level 
by mutual inhibition. The disruption of auxin transport by PIN1 mutation causes patterning defects by preventing the emergence of primordia. However, the patterning of the shoot primordia is not affected during the ablation, suggesting that the activity of PIN1 mediated auxin transport is not compromised during the ablation. Hence studying the regeneration of ablated shoot in mutants defective in auxin transport will shed light on the role of auxin in shoot meristem regeneration.

Another question would be to find the initial cell triggering regeneration. Does the competence for regeneration vary according to cell types? During the repatterning of excised root meristem, all cell types constituting the root tip are involved in regeneration (Sena et al., 2009). The competence to regenerate is not a unique feature of a particular cell type, but instead a common feature for many cell types atleast in the meristematic zone. A similar scenario is found in salamander limb regeneration, where the cells at the site of injury keep a memory of their tissue origin and facilitate for tissue specific proliferation (Kragl and Tanaka, 2009). The regeneration competence is not similar at all developmental stages of differentiated cells. While a high competence for regeneration is retained till $130 \mu \mathrm{m}$ from the root tip, the proficiency of regeneration gradually drops at the proximal end of meristematic region where the cells start entering into the differentiation zone (Sena et al., 2009). The high regeneration potential of young leaves of Arabidopsis and recalcitrance towards regeneration in adult leaves (Sena et al., 2009) reiterates the thought that the competence to regenerate is highly dependent on the developmental stages of cells (Figure 2). The leaf regeneration also confirms that the regeneration potential is distributed among cells which are at their early developmental stages. Unlike root tip and leaf regeneration where the repatterning initiated directly from young differentiating cells without callus formation, the vascular tissue regeneration after bark removal involves the dedifferentiation of adult differentiated xylem cells to pluripotent callus (Zhang et al., 2011). Taken together, the competence to regenerate is conferred onto most of the cell types at their young developmental stages.

\section{DE NOVO ORGANOGENESIS}

The ability of plants to regenerate wounded organs is important for their survival. But for studying the mechanisms involved in regeneration and exploiting the potentials of plant regeneration, in vitro culturing of plant tissue is required. The cells thus cultured are competent to form different organs of an organism when proper developmental cues are provided. When germline stem cells and induced pluripotent stem cells provides an excellent system for studying de novo organogenesis in mammalian system (Donovan and Gearhart, 2001), similar induction of potency for regeneration can be achieved in plants by treating them on high auxin media (Gordon et al., 2007). The callus thus obtained is generally competent to regenerate shoot and an entire plant when treated with proper hormonal levels (Skoog, 1950; Skoog and Miller, 1957; Gordon et al., 2007).

Incubating various explants on auxin rich callus inducing medium (CIM) induces the formation of callus. Callus thus obtained was thought to be dedifferentiated tissue, but recent studies indicate that they are well organized and resemble root
(Sugimoto et al., 2010). Thus, they appear to be partly differentiated tissue. Several lines of evidence point toward this notion as callus derived from various explants display gene expresssion profile similar to lateral root (Sugimoto et al., 2010). Many root specific genes like WOX5, SCR, SHR, PLT1, and RCH1 are expressed in calli obtained from both aerial and ground explants (Table 1) (Atta et al., 2009; Sugimoto et al., 2010).

All plant organs like shoot, leaves and auxiliary branches arise from the pool of meristematic cells already present in apical meristems and axillary buds. However, lateral root emerges out of an already differentiated cell lineage, the xylem pericycle cells (Gordon et al., 2007; Atta et al., 2009). The emergence of meristematic cells from a lineage of differentiated cells is intriguing and provides an excellent model on how pluripotency can be achieved from differentiated cells (Takahashi and Yamanaka, 2006; Yu et al., 2007). The emergence of lateral root at any location on a root is signaled by the establishment of local auxin maxima and activation of auxin responses in the pericycle cells (Celenza et al., 1995; Casimiro et al., 2001). Similarly during callus induction, the auxin rich medium provided externally increases the auxin levels in explants. As both callus induction and lateral root primordium (LRP) initiation is mediated by high auxin conditions (Che et al., 2007), it is fair to speculate that callus emergence from pericycle cells is similar to LRP formation. Furthermore, aberrant lateral root formation4 (alf4) mutant which blocks the initial division of pericycle cells and hence is defective in lateral root initiation (Celenza et al., 1995) completely abolishes callus formation upon CIM treatment (Sugimoto et al., 2010). However, abscisic acid (ABA) treatment of the wildtype explant, which does not prevent lateral root initiation, but prevents its outgrowth is able to form callus (Sugimoto et al., 2010). This suggests that callus development is directly related to the initial development of LRP. Intriguingly the callus formation from the aerial parts of alf4 mutant is also abrogated, suggesting that pericycle-like cells are distributed throughout the plant body and are required for the callus formation (Sugimoto et al., 2010). Several lines of evidence support the notion that pericycle or pericycle-like cells are involved in callus formation irrespective of the context of explants used for regeneration. Sugimoto et al. (2010) analyzed the expression pattern of pericycle specific marker J0121 in aerial parts like leaves and hypocotyl to confirm the presence of pericycle like cells. They found the signal to be enriched around the midvein of cotyledon and leaf and also around the vasculature. Treating the aerial and ground explants on CIM, the area of expression of J0121 get enhanced and once the outgrowth starts to attain its identity, the expression level is reduced. Further, overexpression of four LATERAL ORGAN BOUNDARIES DOMAIN (LBD) genes viz. $L B D 16, L B D 17, L B D 18$, and $L B D 29$ triggers callus formation without external hormonal supplement (Fan et al., 2012). But, when these $L B D$ genes are suppressed, lateral root formation is impaired and no callus is formed even upon CIM treatment (Fan et al., 2012).

Interestingly treatment of explants with diphtheria toxin chain A (DTA) specifically ablates xylem-pole adjacent pericycle cell files (Laplaze et al., 2005) and this abrogates lateral root formation and further blocks callus induction on CIM (Che et al., 2007). Collectively all these evidences hints us that the competence for 
Table 1 | List of key genes involved in de novo organ regeneration process.

\begin{tabular}{llll}
\hline Gene & Role during callus formation & Role during de novo shoot regeneration & References \\
\hline $\begin{array}{l}\text { ALF4 (ABERRANT LATERAL } \\
\text { ROOT FORMATION 4) }\end{array}$ & No callus formation in alf4 mutant & Not described & Sugimoto et al., 2010 \\
\hline $\begin{array}{l}\text { ARR5 (ARABIDOPSIS } \\
\text { RESPONSE REGULATOR 5) }\end{array}$ & $\begin{array}{l}\text { Upregulated at later stages of } \\
\text { callus formation }\end{array}$ & $\begin{array}{l}\text { Expressed in developing shoot meristem } \\
\text { but absent in organ primordia }\end{array}$ & Gordon et al., 2007; Atta \\
CLV3 (CLAVATA3) & Slightly expressed upon & Upregulated in developing shoot meristem & Gordon et al., 2007; Atta \\
& incubation on CIM & et al., 2009 & Cary et al., 2002; Daimon \\
\hline CUC (CUP SHAPED & Upregulated & et al., 2003; Gordon \\
COTYLEDON) & CUC2 is upregulated in developing shoot \\
meristem and organ primordia & $\begin{array}{l}\text { Ectopic over-expression of CUC1/CUC2 } \\
\text { can enhance de novo shoot formation on } \\
\text { SIM. Shoot regeneration efficiency is } \\
\text { reduced in cuc1cuc2 double mutant }\end{array}$
\end{tabular}

$\begin{array}{ll}\text { ESR (ENHANCER OF SHOOT } & \text { ESR1 induced upon incubation on } \\ \text { REGENERATION) } & \text { CIM }\end{array}$

ESR1 transiently gets upregulated soon after transfer onto SIM and declined after 2 days. Over expression of ESR1 or ESR2 enhances de novo shoot regeneration in presence of cytokinin. Reduced shoot regeneration in single and double mutants
Banno et al., 2001; Ikeda et al., 2006; Matsuo et al., 2011 Not described Fan et al., 2012

Overexpression triggered callus formation on hormone free medium and loss of function caused suppression of callus formation

$\begin{array}{ll}\text { LBD (LATERAL ORGAN } & \text { Overexpression triggered callus } \\ \text { BOUNDARIES DOMAIN) } & \text { formation on hormone free } \\ & \text { medium and loss of function } \\ \text { caused suppression of callus } \\ \text { formation }\end{array}$

\begin{tabular}{ll}
\hline PIN1 & Upregulated at early stages of \\
(PIN FORMED 1) & callus formation but gets \\
& downregulated later
\end{tabular}

\begin{tabular}{ll}
\hline PLT1 (PLETHORA1) & Upregulated \\
\hline SCR (SCARECROW) & Upregulated \\
\hline SHR (SHORT-ROOT) & Upregulated \\
\hline STM (SHOOT & Rarely expressed upon incubation \\
MERISTEMLESS) & on CIM \\
Stm-1
\end{tabular}

stm-1

RCH1 (ROOT
CLAVATA-HOMOLOG1)

WOX 5
(WUSCHEL-RELATED
HOMEOBOX 5)

\begin{tabular}{|c|c|c|c|}
\hline WUS (WUSCHEL) & Not expressed in callus & $\begin{array}{l}\text { Upregulated during direct/indirect shoot } \\
\text { regeneration in LRP/callus on SIM } \\
\text { In strong wus-1 mutant, shoot } \\
\text { regeneration reduced to } 5 \% \text { of wild type. } \\
\text { Ectopic overexpression of WUS makes de } \\
\text { novo shoots/somatic embryos on } \\
\text { hormone free medium }\end{array}$ & $\begin{array}{l}\text { Zuo et al., 2002; Gallois } \\
\text { et al., 2004; Gordon } \\
\text { et al., 2007; Atta et al., } \\
\text { 2009; Chatfield et al., } \\
2013\end{array}$ \\
\hline
\end{tabular}

$\begin{array}{ll}\text { Accumulated in developing shoot } & \text { Gordon et al., 2007; Atta } \\ \text { meristem and organ primordia } & \text { et al., } 2009 \\ \text { In pin 1-4 mutant, shoot regeneration } & \\ \text { decreased to 20\% of wild type } & \end{array}$

$\begin{array}{ll}\text { Downregulated } & \text { Atta et al., 2009; } \\ & \text { Sugimoto et al., } 2010\end{array}$

Not described Sugimoto et al., 2010

Not described Sugimoto et al., 2010

Upregulated in developing shoot meristem Barton and Poethig,
In stm-1 mutant, shoot regeneration 1993; Gordon et al., decreased to $15 \%$ of wild type 2007; Atta et al., 2009

Upregulated Downregulated Atta et al., 2009

Upregulated Not described Sugimoto et al., 2010

Upregulated at early stages of
callus formation but gets downregulated later 
callus formation is largely influenced by the ability of the plant to initiate lateral roots from the pericycle cells (Laplaze et al., 2005; Atta et al., 2009). Irrespective of the explants used for callus induction, callus arises from pericycle or pericycle like cells and competence for callus induction is provided by pericycle specific genes (Figure 5) (Sugimoto et al., 2010). The transformation of pericycle cells to organogenic callus occurs pretty rapidly and the competence is maintained only for a specific time window. The competence for organogenesis is acquired by incubation of explants on CIM for a minimum of $48 \mathrm{~h}$. Within this period, PIN1 marks the callus outgrowth (Gordon et al., 2007). Subsequently the auxin response exhibited by DR5 promoter spikes to a maximum. Further incubation on CIM leads to the decrease in the domain and expression levels of both PIN1 and auxin response. As their levels go down, the expression levels of cytokinin responsive ARABIDOPSIS RESPONSE REGULATOR 5 (ARR5) and boundary genes CUP SHAPED COTYLEDON $1(C U C 1)$ and CUC2 increases and gets localized to the proliferating callus (Figure 4) (Gordon et al., 2007). The callus is competent to form organs like shoot and root during these stages. But the competence thus obtained is transient. After incubation of the callus in CIM for more than 14 days, the competence to switch to shoot fate is rapidly reduced and the callus gets differentiated completely to root fate (Christianson and Warnick, 1983; Gordon et al., 2007).

The next hurdle for de novo organogenesis is the patterning of pluripotent callus to specific organs. It took 19 years after the discovery of callus inducing medium for finding the proper medium for converting the callus to desired organ fates. Skoog and Miller (1957) discovered that high cytokinin to auxin ratio induces shoot regeneration from callus and high auxin concentration leads to formation of root from the medium (Skoog and Miller, 1957). The induction of root from callus is easier and trivial because the callus itself is having root identity (Figure 4). Therefore, the root induction needed the incubation on root inducing medium (RIM) which is rich in auxin.

But, shoot organogenesis is comparatively complex as new set of genes need to be turned on. Some of the genes expressed in callus get spatially regulated and several key regulatory interactions get established to switch the root fate to shoot (Gordon et al., 2007; Atta et al., 2009). Just after the incubation on cytokinin rich shoot inducing media (SIM), the callus which was expressing root specific genes all throughout undergoes a morphosis to a mass of cells that is having a localized expression of shoot specific genes (Figure 4). The SIM induction of calli causes partitioning of cell fates evident by differential expression of different markers (Gordon et al., 2007). It induces the spatial and temporal localization of shoot patterning genes like CUC2 and expression of shoot meristem regulators like WUS (Gordon et al., 2007). The auxin responsive DR5 expression also gets localized to the regions of callus that did not initiate shoot while cytokinin responsive ARR5 and polar auxin transporter PIN1 gets confined to those areas of callus that is low on DR5 expression (Gordon et al., 2007; Atta et al., 2009). Simultaneous to PIN1 expression, ARABIDOPSIS THALIANA MERISTEM L1 LAYER (ATML1) gets upregulated in the superficial layer of shoot promeristem. Consequently, the expression domain of WUS is confined to the center of the promeristem and another important shoot meristem regulator, SHOOT MERISTEMLESS (STM) is accumulated in a ring of surrounding cells within the promeristem, meanwhile the CUC2 expression is delocalized to the site of shoot primordia formation (Figure 4) (Gordon et al., 2007). Subsequently CLAVATA3 (CLV3), stem cell marker, is expressed in the central zone of shoot meristem just above to the WUS expression domain, where the stem cell niche resides. As shoot primordia are initiated from the peripheral zone of the shoot meristem, PIN1 gets upregulated in the shoot primordia (Table 1) (Gordon et al., 2007).

The callus formed upon hormonal treatment has great resemblance to LRP. Hence it is expected that the LRP should give rise to de novo organs without the formation of callus. The direct regeneration of shoot from LRP when treated with cytokinin rich media (Atta et al., 2009; Chatfield et al., 2013) suggests that shoot regeneration do not always need callus formation, but the LRP cells are competent enough to trigger the shoot fate directly (Figure 5). The direct shoot regeneration from pericycle cells adjacent to protoxylem, which form the LRP, suggests that the pericycle cells are highly flexible to acquire different cell fate than only converting itself to root-like callus cells. Immediately after cytokinin treatment the gene expression profile of LRP changes and it expresses shoot meristem markers like WUS, CLV3, and STM that are not normally expressed in root (Atta et al., 2009; Chatfield et al., 2013). Changes in auxin gradient and polar localization of PIN1, together with the dynamic expression of shoot meristem regulators define shoot meristem formation from LRP in 5-6 days of induction on cytokinin rich medium (Atta et al., 2009). Interestingly, ectopic expression of WUS is sufficient to initiate de novo shoot formation directly from Arabidopsis root (Gallois et al., 2004). The mis-expression of WUS in the root initiates to change the entire gene expression profile of root into shoot specific. Taken together, the growing body of evidences suggests that the pericycle cells have amazing regenerative ability and it can be converted into lateral root, shoot, or callus depending upon the different hormonal treatment.

De novo organogenesis can be obtained either directly from root explants, or through an intervening callus stage. But for the regeneration to occur the presence of competent pericycle cells that can initiate LRP is required. When LRPs act as the initiation point in direct regeneration, presence of comptent pericycle is required for callus formation. The callus which has a LRP identity when incubated on cytokinin rich media undergoes a morphosis and expresses shoot meristem regulators. Not surprisingly, mutation in shoot meristem regulators like CUC2, WUS, STM, and PIN1 display decrease in de novo shoot formation. However, mutation in these genes do not abolish the de novo shoot initiation completely (Barton and Poethig, 1993; Daimon et al., 2003; Gordon et al., 2007). Future studies should unravel additional key regulators that provide competence for de novo organogenesis from callus.

\section{microRNA MEDIATED REGULATION DURING DE NOVO SHOOT REGENERATION}

Recent studies on microRNAs (miRNAs) show their role in de novo organogenesis. These small endogenous non-coding RNAs (21-24 nucleotide length) that regulate gene expression at 


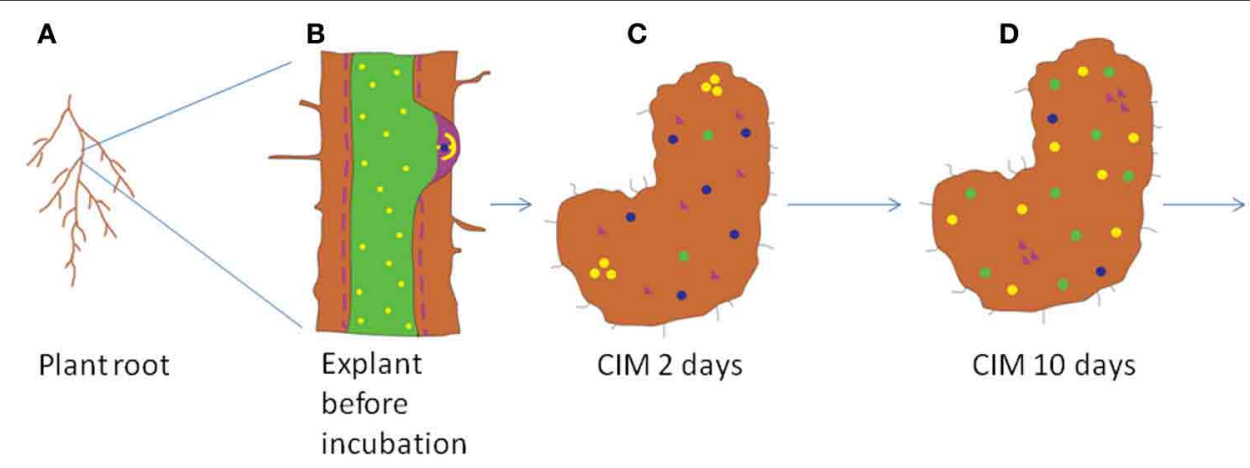

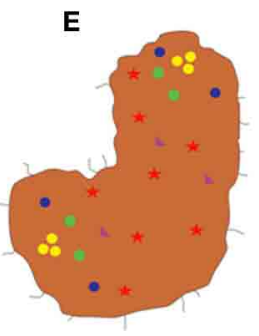

SIM 2 days
$\mathbf{F}$

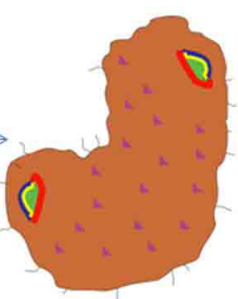

SIM, emergence of promeristem
G

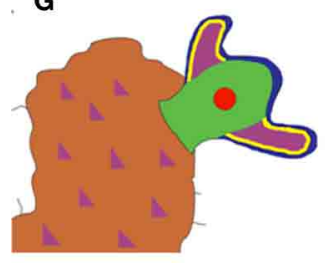

ARR5 (Cytokinin)
DRS (Auxin)
$\bigcirc$ CUC2
WUS
PINI

De novo Shoot

formation
FIGURE 4 | Schematic of expression dynamics of regulatory genes during de novo shoot organogenesis. The root explant of Arabidopsis $(\mathbf{A}, \mathbf{B})$ with an emerging lateral root expresses auxin responsive DR5 at the tip of the LRP (purple) coinciding with the expression domain of PIN1 (magenta), cytokinin responsive ARR5 (green) in LRP and root stele and CUC2 (yellow) in a subset of cells in lateral root meristem and root stele (B). The expression domain of auxin and PIN1 expands in the proliferating callus 2 days after CIM treatment, while CUC2 gets accumulated in patches and cytokinin level start rising (C). Ten days after CIM induction,
CUC2 and ARR5 expression is seen throughout the callus while PIN1 and DR5 are weakly expressed in callus (D). Two days post SIM induction, CUC2, and ARR5 get confined to patches while WUS expression is induced throughout the callus (E). Regions of high CUC2 and ARR5 expression marked the emerging shoot promeristem while WUS is expressed in the peripheral cells. DR5 expression is low at the area of shoot meristem emergence (F). Once the de novo shoot emerges out, WUS occupies the central niche with high auxin and CUC2 levels are confined to primordial (G) transcriptional and post-transcriptional level in plants and animals are implicated to have crucial roles in development (Bartel, 2004). In addition to the regulation of developmental processes like embryogenesis, meristem organization, leaf polarity, and vascular development (Jung and Park, 2007; Liu et al., 2007), they are involved in cell proliferation and differentiation. In plants, many miRNAs are differentially regulated during callus formation and de novo shoot formation (Luo et al., 2006; Chen et al., 2011; Qiao et al., 2012; Liu et al., 2013). A unique set of miRNAs are differentially expressed during embryogenic callus formation in rice (Luo et al., 2006; Chen et al., 2011). Similarly, a group of miRNAs which are significantly abundant during callus formation and de novo shoot regeneration in Arabidopsis has been identified (Qiao et al., 2012). The differential expression of few miRNAs in totipotent and non-totipotent calli reveals their role in cell proliferation and differentiation. One of such miRNA is miR160 which is scarce in totipotent calli but abundant in non-totipotent calli (Qiao et al., 2012). Interestingly miR160 negatively controls the expression of AUXIN RESPONSE FACTOR10 (ARF10) gene during de novo shoot regeneration (Qiao et al., 2012). miR160 mediated regulation of ARF10 is also pronounced during seed germination and post embryonic development in Arabidopsis (Liu et al., 2007). Overexpression of
miR160 leads to reduction in shoot regeneration. Meanwhile the miR160 resistant form of ARF10, mARF10, shows high regeneration potential (Qiao et al., 2012). Other miRNAs like miR165/166 are involved in the regulation of shoot meristem maintenance, leaf polarity and floral development in in planta (Jung and Park, 2007). Intriguingly, these two miRNAs are also involved in shoot regeneration in Arabidopsis in parallel to WUS/CLV3 and REV pathways (Liu et al., 2013). It has been shown that miR164 controls the dynamic expression of CUC2 during the organ initiation in in planta (Peaucelle et al., 2007). But the expression pattern of CUC2 remained the same in both transcriptional and translational fusion during early stages of de novo shoot regeneration (Gordon et al., 2007). So, whether miR164 regulates CUC2 expression during de novo organogenesis is yet to be elucidated. Although efforts have been put to identify some of the miRNAs during callus formation and shoot regeneration, a complete picture of miRNA regulated gene expression during de novo shoot regeneration is not clear and hence a comprehensive study is demanded in this direction. Together, the growing body of evidences suggest that miRNA mediated post-transcriptional regulation is crucial for the cells to maintain pluripotency and to differentiate and give rise to lateral organs during in vitro culture. 

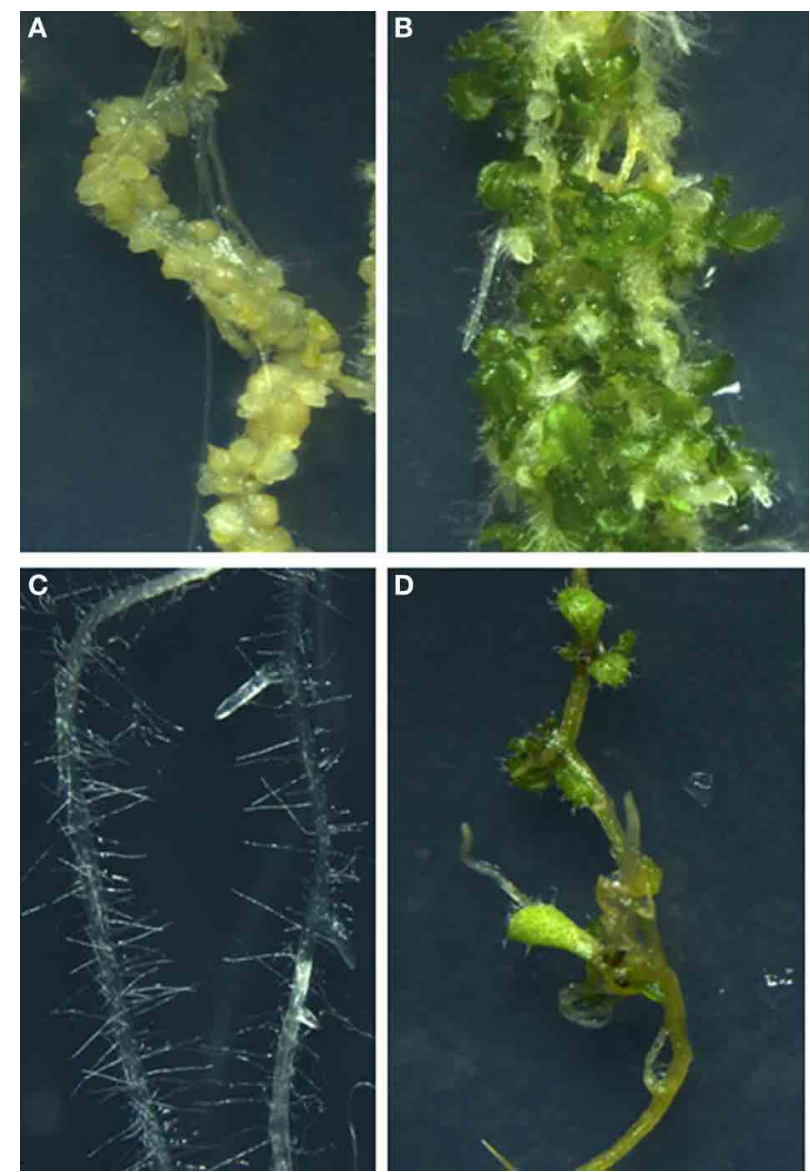

FIGURE 5 | Direct and Indirect de novo organogenesis. Callus formation from Arabidopsis root explant on auxin rich callus inducing medium (CIM) (A). De novo shoot regeneration on callus incubated on cytokinin rich shoot inducing medium (SIM) (B). Arabidopsis root explant with lateral root primordia from where lateral root emerges out incubated on normal MS medium (C). Direct shoot regeneration from lateral root primordia of Arabidopsis root upon incubation on cytokinin rich medium (D).

\section{SOMATIC EMBRYOGENESIS}

Somatic embryogenesis can be an attractive tool to study the developmental events during zygotic embryogenesis particularly when the zygotic embryos are not easily accessible for carrying out biochemical and molecular analysis. Somatic embryos are defined as structures that are having a somatic cell origin but share the morphology and anatomy of zygotic embryo (Bassuner et al., 2007; Birnbaum and Sanchez Alvarado, 2008; Gliwicka et al., 2013). During somatic embryogenesis, differentiated cells reverse their developmental program and acquire embryonic potential (El Ouakfaoui et al., 2010; Gliwicka et al., 2013). Though somatic embryo and zygotic embryo arise from different lineages of cell, the developmental processes involved are mostly conserved (Zimmerman, 1993; Jimenez and Bangerth, 2001; Birnbaum and Sanchez Alvarado, 2008; Bai et al., 2013). Like the zygotic embryo, somatic embryo proceeds from globular stage to torpedo stage and has many morphological similarities to the stages of zygotic embryogenesis (Meinke, 1991; Zimmerman, 1993; Su et al., 2009). Somatic embryogenesis from somatic cells is achieved by incubating the explants on medium containing specific amount of synthetic auxin 2, 4-dichlorophenoxyacetic acid (2, 4-D) and subsequent transfer to auxin free medium (Sugiyama, 2000; Mordhorst et al., 2002). Somatic embryo can be easily distinguished from other structures like adventitious shoots and fused shoots which are formed during the induction of a somatic embryo by its bipolar nature (shoot and root pole). The bipolar nature is evident in a somatic embryo by the localized expression of WUS and CLV3 in the shoot meristem of the heart shaped stage (Su et al., 2009) and PIN4 expression and high DR5 activity in its root meristem (Bassuner et al., 2007). While the adventitious and fused shoot remains attached to the explant and does not develop an anatomically recognizable root meristem, the somatic embryo which arises of a small cell cluster detaches fully or just has a thin connection with the callus and has a distinguishable shoot and root (Pillon et al., 1996; Mordhorst et al., 2002; Gaj et al., 2005; Bassuner et al., 2007). Other features of the somatic embryos include the absence of trichomes in the first pair of leaves (cotyledons), thick cell wall, big nucleus, and single nucleolus.

Like zygotic embryogenesis, a complex and similar set of regulatory interactions are involved during somatic embryogenesis which provide the necessary information to acquire new fate and for further development. Unraveling the molecular mechanism governing the somatic embryogenesis is important to improve the existing regeneration protocol. The role played by some of the key players of somatic embryogenesis such as WUS (Zuo et al., 2002), AGAMOUS LIKE15 (AGL15) (Harding et al., 2003), BABY $B O O M(B B M)$ (Boutilier et al., 2002; El Ouakfaoui et al., 2010), EMBRYOMAKER (EMK/AIL5) (Tsuwamoto et al., 2010), and LEAFY COTYLEDON (LEC) (Gaj et al., 2005; Guo et al., 2013) have been recently elucidated. Ectopic overexpression of WUS, a homeodomain transcription factor, induces somatic embryos in the root and shoot apices of intact seedlings as well as root explants of Arabidopsis on hormone free medium (Zuo et al., 2002). Even when Arabidopsis AtWUS gene is overexpressed in cotton plants, it triggers somatic embryogenesis (BouchabkeCoussa et al., 2013) signaling that the developmental processes involved in somatic embryogenesis may be conserved across species. Similarly, members of the AP2 family of transcription factors such as EMK/AIL5 (Tsuwamoto et al., 2010) and BBM (Boutilier et al., 2002; El Ouakfaoui et al., 2010) have the capacity to induce somatic embryogenesis when ectopically expressed. In $B B M$ or AIL5 overexpressed seedlings, somatic embryos are formed on the cotyledon, leaf, petiole, and shoot apex (Boutilier et al., 2002; El Ouakfaoui et al., 2010; Tsuwamoto et al., 2010). During the somatic embryogenesis in soybean plants, the mRNA levels of GmPLT2 and GmAIL5, homologs of Arabidopsis PLT2 and AIL5, respectively, have been shown to be upregulated (El Ouakfaoui et al., 2010).

The levels of both exogenous and endogenous auxin play an important role during somatic embryo formation (Su et al., 2009; Bai et al., 2013; Wojcikowska et al., 2013). The process of somatic embryogenesis requires appropriate levels of external auxin supply (Wojcikowska et al., 2013). Initially when the somatic explant is treated with 2,4-D rich medium, embryonic callus is induced. The increased level of exogenous auxin enhances ethylene biosynthesis by activating 1-aminocyclopropane-1-carboxylate 
synthases (ACSs) (Abel et al., 1995; Tsuchisaka and Theologis, 2004; Bai et al., 2013). Thus, an increased level of ethylene is maintained in the embryonic callus. The ethylene thus induced helps in auxin transport and regulates asymmetric auxin distribution by inhibiting auxin biosynthetic YUCCA (YUC) genes (Muday et al., 2012). When this callus is treated with hormone free medium, due to the absence of external auxin, ethylene levels start to diminish (Bai et al., 2013). Thereby the control on endogenous auxin synthesis is lifted and the endogenous expression of YUC genes is reinstated. LEC2 is a seed specific gene (Santos-Mendoza et al., 2005) and is a key regulator of embryo and seed development (Braybrook and Harada, 2008) which gets upregulated during somatic embryogenesis. It is epigenetically regulated by PICKLE (PKL) and FERTILIZATION INDEPENDENT ENDOSPERM (FIE) (Ogas et al., 1999; Bouyer et al., 2011) during other developmental stages. The activation of $L E C 2$ also helps in increasing the levels of endogenous auxin synthesis indirectly. The polarization of PIN1 within $16 \mathrm{~h}$ of induction along with the $L E C s$ and ethylene plays an important role in setting the auxin gradient (Liu et al., 1993; Su et al., 2009). During these initial stages of somatic embryogenesis, WUS and PIN1 occupy the areas in the callus where the amount of auxin is less (Su et al., 2009). After $36 \mathrm{~h}$ of induction, WUS and PIN1 get co-localized in somatic pro-embryo which further proceed for the completion of the process of somatic embryogenesis (Su et al., 2009). Treatment of embryonic calli with auxin transport inhibitor N-1-naphthylphthalmic acid (NPA) causes the suppression of WUS induction and the inhibition of somatic embryogenesis. Thus, establishment of auxin gradients and polar localization of PIN1 somehow regulate the expression of WUS in the embryonic calli and the cumulative effort of auxin gradient and WUS expression lead to the formation of somatic embryos (Su et al., 2009). Later, the stem cells of the embryo are marked by a nonoverlapping expression of CLV3 (Su et al., 2009). Meanwhile LEC2 which got upregulated in the initial stages of somatic embryogenesis, starts accumulating in cotyledon primordia of the emerging embryo. CUC2 also follows a localization and expression pattern of $L E C 2$ and gets compartmentalized to the cotyledon boundary and the STM levels increase till the proper somatic embryo is defined (Su et al., 2009).

Once the initial competence is set by treatment of explants with auxin rich media, rest of the processes involved in somatic embryogenesis follows up like a cascade. Gao et al. (2008) have shown that auxin can act as a self-organizing signal to direct polar auxin transport and to establish auxin gradient. It is quite reasonable to think that the same self-organizing signal is active to establish the initial auxin gradient during the early stages of somatic embryogenesis and regeneration. Once this signal is set, it promotes the polar localization of PIN1 and leads to the formation of somatic embryo. This auxin gradient initiates the process of regeneration. But the processes involved in setting the initial gradient of auxin that give competence for somatic embryogenesis remain largely unknown. Taken together, the molecular pathways and hormonal controls involved in de novo organogenesis are similar, both these processes end up forming two distinct structures. When somatic embryogenesis reflects the totipotency of the cell, de novo organogenesis presents its pluripotency. Further studies on the cumulative roles of plant hormones like cytokinin and ethylene and control on the endogenous levels of auxin by LEC and polar auxin transport will shed light on the early processes involved in setting the competence for somatic embryogenesis.

\section{EPIGENETIC MODIFICATIONS DURING REGENERATION}

Chromatin remodeling is the principal phenomenon underlying reprogramming that occurs during regeneration. The fate of the cells at the site of damage is switched to adopt a new fate in the process of regenerating the lost organ. It is accomplished by reorganization of the gene expression pattern, brought about by various epigenetic mechanisms (Barrero and Izpisua Belmonte, 2011). The epigenetic mechanisms that operate in both plants and animals are similar in terms of their function and mode of action. DNA methylation and post-transcriptional modifications of $\mathrm{N}-$ terminal tails of core histone proteins such as acetylation, methylation, ubiquitination, phosphorylation, and ADP ribosylation, occurring primarily at the upstream regulatory sequences of specific genes are the major contributing mechanisms to chromatin remodeling (Jenuwein and Allis, 2001; Richards and Elgin, 2002). DNA methylation, histone deacetylation and histone methylation at specific amino acid residues such as lysine 9 of histone 3 (H3K9), lysine27 of histone3 (H3K27), lysine20 of histone4 (H4K20) negatively regulate the gene expression, while histone acetylation, DNA hypomethylation and histone methylation, specifically at lysine4 of histone3 (H3K4), lysine36 of histone3 (H3K36) and lysine79 of histone3 (H3K79) work as positive switch of gene expression (Wade et al., 1997; Jenuwein and Allis, 2001; Lusser et al., 2001; Zhang and Reinberg, 2001; Richards and Elgin, 2002). The epigenetic regulators act by modifying the structure of chromatin, which in turn alter the accessibility of chromatin to the transcriptional machinery resulting in the modulation of gene expression (Callinan and Feinberg, 2006). Transcriptional repression via $\mathrm{H} 3 \mathrm{~K} 27$ methylation is mediated by Polycomb group $(\mathrm{PcG})$ of proteins. PcG proteins are highly conserved proteins and play a pivotal role in long-term gene silencing. The PcG proteins form two distinct protein complexes, Polycomb repressive complex1 (PRC1) and PRC2 (Francis and Kingston, 2001; Saurin et al., 2001; Cao et al., 2002; Czermin et al., 2002; Kuzmichev et al., 2002; Muller et al., 2002). While PRC2 is involved in leaving an epigenetic signature by trimethylating H3K27 (Cao et al., 2002; Czermin et al., 2002; Kuzmichev et al., 2002; Muller et al., 2002), PRC1 complex stabilizes the methylation mark via ubiquitination of lysine 119 and lysine 121 on H2A, in animals and plants, respectively. This causes localized heterochromatin formation, resulting in gene repression (Schuettengruber and Cavalli, 2009).

In Arabidopsis, the PRC2 proteins, CURLY LEAF (CLF), SWINGER (SWN), and EMBRYONIC FLOWER2 (EMF2) are implicated to play a major role in the formation of callus. The redundant proteins, CLF and SWN are homologous to Enhancer of Zeste, E(z) (Chanvivattana et al., 2004), while EMF2 is homologous to Suppressor of Zeste $12(\mathrm{Su}(\mathrm{z}) 12)$ of Drosophila (Yoshida et al., 2001). clf swn double mutant and emf2 mutant, are defective in callus formation, from cotyledons and leaf blade but not from root (He et al., 2012). This suggests the plausible role of PRC2 components in suppressing 
the leaf-specific regulatory genes, which is essential for the transition of leaves into pluripotent callus (Figure 6). Recent pioneering work on root and leaf explants have shown that promoter DNA hypermethylation dependent transcriptional repression of specific genes, viz., GSTU10, MAPK12, and BXL1, primarily mediated by METHYLTRANSFERASE1 (MET1) and DOMAINS REARRANGED METHYLTRANSFERASE2 (DRM2) methyl transferases, is an essential criteria for the establishment of undifferentiated state in callus cells (Figure 6) (Berdasco et al., 2008). There are also studies which show the association of promoter DNA hypomethylation mediated upregulation of several members of the NAC (NAM/ATAF1/CUC2) domain family with the acquisition of pluripotency in the protoplast cells of leaves (Avivi et al., 2004). This implies that the establishment and maintenance of undifferentiated state in plant cells necessitates both upregulation and downregulation of genes brought about by changes in the levels of DNA methylation. PICKLE (PKL) is a pivotal chromatin remodeler which belongs to Chromodomain-Helicase-DNA binding3 (CHD3)/CHD4 family of proteins (Eshed et al., 1999; Ogas et al., 1999). Recent studies elucidated the role of PKL as a negative regulator of cytokinin response during regeneration as the pkl/cytokinin hypersensitive2 (ckh2) mutant displayed sensitivity to low levels of cytokinin and proliferated into green colored calli at considerably lower levels of cytokinin, compared to wild type (Furuta et al., 2011).

During de novo shoot regeneration, WUS plays a key role as its domain of expression specifies shoot organizing center, which confers stemness to the neighboring cells (Schoof et al., 2000; Gallois et al., 2004; Gordon et al., 2007). Thereby, WUS expression can be positively correlated to de novo shoot regeneration. Recent studies conducted by Li et al. (2011) illustrated the striking correlation between the epigenetic control on levels of WUS expression and developmental rates of de novo shoot regeneration. For this, they exploited mutants defective in the following salient epigenetic regulators involved in DNA methylation

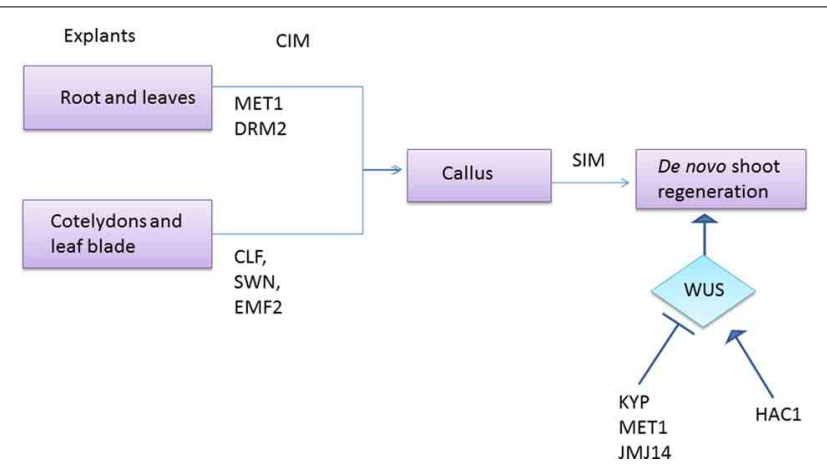

FIGURE 6 | Role of epigenetic modifiers in de novo shoot formation. Explants from various parts of the plant are having different epigenetic modifiers to control gene expression during callus formation. When MET1 and $D R M 2$ are involved in the callus formation from root and leaves, CLF, $S W N$, and EMF2 does the same in explants derived from cotyledon and leaf blade. Further control on shoot organogenesis is achieved by monitoring the expression of WUS, which is epigenetically inhibited by KYP, MET1, and JMJ14 and is enhanced by HAC1. and histone modifications viz., MET1, encoding for DNA methyltransferase, KRYPTONITE $(K Y P)$ for the H3K9 methyltransferase, JMJ14 for H3K4 demethylase, and HAC1 for the histone acetyl transferase. The met1, kyp, and jmj14 mutants are associated with epigenetic changes involving increased transcriptional activation of their downstream targets and they displayed precocious regeneration of de novo shoots. Meanwhile hac1 mutant, associated with more repressed transcription showed delayed developmental rate of de novo shoots when the individual mutant calli were placed on SIM. Strikingly, the levels of WUS expression was significantly enhanced in met1, kyp, and jmj14 mutant calli while it was reduced in hacl mutant calli when compared to wild type calli at same time points on SIM, suggesting that these epigenetic regulators control the developmental rates of de novo shoot regeneration by dynamically regulating WUS expression (Figure 6) (Li et al., 2011).

As already described, somatic embryogenesis is a regenerative process; wherein the differentiated somatic cells dedifferentiate to form somatic embryos that further develop into complete plantlets. clf swn double mutant exhibits somatic embryo formation from masses of undifferentiated cells formed on the plantlet tissues (Chanvivattana et al., 2004). This is a spectacular example for the involvement of PRC2 components in the maintenance of differentiated state, which is in contrast to their role in the acquisition of pluripotency as stated earlier. $P K L$ is also implicated in the maintenance of differentiated state in plants and acts via suppression of LEC1, an activator of embryonic development (Ogas et al., 1999). pkl mutant exhibits characteristics of embryonic tissue in the primary root meristem, which would grow thick and become opaque and green after an initial period of normal growth and the primary roots are named as pickle roots. The $p k l$ roots, when excised and cultured on a normal MS medium without the exogenous supply of plant hormones, showed development of somatic embryos (Ogas et al., 1997). These findings entail the potency of PRC2 components and PKL to enable the cells sustain the state of differentiation as their loss of function evoke cellular reprogramming resulting in the acquisition of a dedifferentiated state, leading to the development of somatic embryos.

These leading bodies of experiments performed in Arabidopsis, gives a flavor of the diversifying and also contrasting roles of chromatin remodeling during regeneration. These involve the maintenance of differentiated state, the loss of differentiated state and acquisition of pluripotency and dynamic regulation of gene expression during de novo shoot formation. However, the complete picture on the intricate entanglement of the players of chromatin remodeling with each step of regeneration in plants is yet to be unraveled.

\section{REGENERATION: AN EVOLUTIONARY PERSPECTIVE}

Regeneration is a process that is spread in the domain of life and the strategies employed for regeneration show a striking similarity across kingdoms (Figure 1). When the specialization of various cells to carry out different functions required for a multicellular organism gives a convincing reason for the confinement of regenerative cells to their niches, it is quite surprising to see that the ability to divide is compartmentalized even in prokaryotes. Bacteria were long thought to be following identical division 
producing daughter cells that are competent for further divisions. But Caulobacter crescentus, an $\alpha$-proteobacterium divides asymmetrically producing a sessile stalk cell and a motile swarmer cell. The replication of the motile cell is under tight regulation of CtrA, which represses cell division by binding to origin of replication (Domian et al., 1997; Quon et al., 1998). Once proper signals are received, $C \operatorname{tr} A$ is dephosphorylated and degraded thereby mediating the cell fate change to the stalk cell which is competent for reproduction (Domian et al., 1997; Bastedo and Marczynski, 2009). As described earlier, epigenetic control which play a crucial role in determining the competence for regeneration in plants is active even in bacteria (Domian et al., 1997). The reprogramming of the swarmer cell to stalk cell can be seen as the primordial form of reprogramming that is seen during tissue regeneration in higher plants and animals. And the asymmetric division seen in the bacteria like Caulobacter is one of the most primitive modes of reproductive asymmetry that is seen in higher plants and animals, where a specialized group of cells (stem cells) retain their ability to divide perpetually without getting committed to a specific fate while other loses competence to divide indefinitely and differentiates into specific fates. All these evidences point us to the conclusion that strong evolutionary forces are responsible for controlling the regeneration of an organism. The spatiotemporal localization of the stem cells which plays an important role in determining the regenerative biology of an organism is modulated in different organism through the course of evolution.

Algae are the simplest members of the plant kingdom. The taxa contain diversity of species that may either be single cellular or multicellular showing striking ability of regeneration. Most of the multicellular algae just consist of a structure called thallus which is a mass of undifferentiated cells, but have structures analogous to plant organs of higher plants (Goldstein, 1973). When most of the other multicelluar algae are competent to repair wounds by regenerating new cells and even regenerate an entire algal body from explants containing just a few cells under natural conditions (Aguirre-Lipperheide et al., 1995; Huang and Fujita, 1997) a few members of the division, like Acetabularia goes a step ahead by regenerating the wounded cell (Mandoli, 1998). The animal counterpart for algae would be phylum porifera, which exhibits a simple body plan with very few cell types. As in algae the sponges are also able to regenerate upon wounding or an entire organism from just a lump of cells (Hoppe, 1988; Duckworth et al., 2003).

Interestingly, bryophyte which exhibits more complex body plan than the algae follows a similar pattern in regeneration. The body plan of the haploid embryophyte of bryophytes which occupies the major phase of its life cycle also consists of thallus. So the number of lineages of cells is highly limited. This could be the reason for the remarkable regenerative ability of mosses, where they can regenerate any wounded tissue or an entire plant from the powdered explants without any external hormone supply (La Farge et al., 2013). The mode of regeneration exhibited by cnidarians (includes jellyfish, sea anemones, and corals) is strikingly similar to that exhibited by bryophytes (Lenhoff and Lenhoff, 1986). They have a simple body plan like algae with just two germ layers and a few cell lineages. As in the algae, the cnidarians can also regenerate an entire organism from just a clump of cells (Noda, 1971; Gierer et al., 1972; King and Newmark,
2012). Even dissociated single cells can rejoin to regenerate an entire organism. Seemingly the competence for regeneration is spread throughout body of these organisms with relatively simpler cellular organization (Gierer et al., 1972; King and Newmark, 2012).

In pteridophytes, the sporophytic generation which occupied a very small part of the life cycle of algae and bryophytes has equal representation as the gametophyte. Thus, the regenerative competence of sporophytes was put to test in these taxa of plants. Intriguingly in ferns, plant explants of the gametophyte showed remarkable potential for regeneration in hormone free medium (Banks, 1999; Kazmierczak, 2003; Menendez et al., 2009; Abul et al., 2010; Somer et al., 2010). While in the sporophyte though the potential for regenerating an excised organ remained, the explants were recalcitrant to regenerate an entire organism when no external hormone is supplied (Ferna'ndez et al., 1993, 1997). The callus induction by hormones was required for reprogramming the cells to a competent state.

The sporophyte of flowering plants is the most complex division in the plant kingdom. Unlike all other divisions, they form many organs and have many lineages of cells specialized for various purposes. This specialization comes with a price on the regenerative potential of the plant. In angiosperms, not many cell lineages are competent for regeneration and the ones that can form an entire plant from explants in a hormone free medium are highly confined to few niches (Atta et al., 2009). But even in angiosperms the highly diminished gametophytes retain their regenerative potential as evident from pollen grain which can undergo embryogenesis under stressful without external hormones (Reynolds, 1997; Segui-Simarro et al., 2011; Soriano et al., 2013). Dicotyledonous plants like Arabidopsis have cambium stem cells localized to specific niches in their body plan that helps in secondary thickening of the plant. But monocots that evolved relatively recently from dicots lack the cambium meristem and have a limited amount of meristematic cells in their body plan thereby narrowing the regenerative potential. The story in animals is also not very different. In humans, embryonic stem cells retain the ability to regenerate entire organisms while all other cells have lost their competence to regenerate a complete individual (Wong et al., 2011) But some residual competence is retained by stem cells present in the adult body which does the maintenance and repair of the bodily organs as it is done in plants.

As the process of evolution produces more and more complex organisms with complex organs and organ systems, myriads of cell lineages dedicated for specific processes, the reproductive potential is traded off. The competence for regeneration is tightly controlled in higher organisms and external agents are required to reinstate regenerative potentials to a differentiated cell. This is the common feature seen in both plants and animals. Further, localizations of regenerative cells are restricted spatially and temporally during the organismal development in both animals and plants.

\section{FUTURE PERSPECTIVES}

Elegant set of experiments using QC ablation in the root meristem and regeneration from cut meristem shed light on contribution of stem cells maintenance in regeneration (Xu et al., 2006; Sena et al., 
2009). However, absolute necessity of stem cells for regeneration yet needs to be demonstrated, in particular after decapitating the root meristem. It is tempting to speculate that stem cells are required for regeneration and partial maintenance of stem cells can still lead to regeneration as it was seen in the experiments done by Sena et al. (2009). Intriguingly, only sub sets of root meristem cells located in vicinity of stem cell niche have potential to regenerate rest of the meristem after decapitation suggesting sheer ability to divide may not suffice to provide regeneration competence. Combination of cell fate determining factors, epigenetic regulators, and dynamic accumulation as well as synthesis of plant hormone are likely to be the key players. Careful in depth analyses of differences in the molecular environment between the root meristem cells with ability to regenerate and cells which lack regeneration potential will be instrumental to understand the molecular mechanisms to establish the competence.

Remarkable ability to regenerate entire organism from different explants has been exploited for micropropagation of various plant species. However, unlike animal kingdom, molecular insights into plant regeneration remained largely unknown till recently. Present studies have begun to uncover molecular nature of competence and order of events during regeneration in model dicot species Arabidopsis thaliana. One of the most recent striking finding is the nature of callus which was long thought as dedifferentiated tissue. Expression patterns of genes combined with genetic studies suggest that callus is root like tissue and callus originates from pericycle like cells from various explants including some of the aerial organs such as cotyledons and petals (Sugimoto et al., 2010). It will be revealing to include explants like stem and leaves of different plant species to evaluate whether cells other than pericycle like cells also participate to generate callus mass and whether these other cells also pass through competence state resembling pericycle-like cells.

It is important to note that callus is not only derived upon external hormone application but it can also be formed upon wounding (Pang et al., 2008; Zhang et al., 2011). An interesting question is whether callus derived upon wounding have potential to regenerate entire plant body plan. Recent studies demonstrate that Arabidopsis WIND1, which is involved in wound-induced callus (Iwase et al., 2011), can also trigger callus formation in other plants species. An important step ahead would be to utilize these calli as tools to probe their competence to regenerate complete plant body. Despite the fact that we have begun to understand the callus identity, how cells of initial explants acquire competence to generate pluripotent callus, remains elusive. Furthermore, it will be crucial to unravel how the competent callus is generated and how various regulatory interactions necessary for shoot formation are assembled on rough callus surface.

\section{ACKNOWLEDGMENTS}

Kalika Prasad acknowledges early start up grant from Indian Institute of Science Education and Research, Trivandrum and the grant from Department of Biotechnology, Govt. of India. Ajai Joseph Pulianmackal is recipient of KVPY fellowship, Abdul V. K. Kareem is supported by IISER TVM fellowship, Kavya Durgaprasad and Zankhana Bhanuprasad Trivedi are recipients of INSPIRE fellowship. We thank Ajeesh MO for helping us with the schematics.

\section{REFERENCES}

Abel, S., Nguyen, M. D., Chow, W., and Theologis, A. (1995). ACS4, a primary indoleacetic acid-responsive gene encoding 1-aminocyclopropane1-carboxylate synthase in Arabidopsis thaliana. Structural characterization, expression in Escherichia coli, and expression characteristics in response to auxin [corrected]. J. Biol. Chem. 270, 19093-19099. doi: 10.1074/jbc.270.32.19093

Abul, Y., Mene'ndez, V., Go'mez-Campo, C., Revilla, M. A., Lafont, F., and Ferna'ndez, H. (2010). Occurrence of phytohormones in Psilotumnudum. J. Plant Physiol. 167, 1211-1213. doi: 10.1016/j.jplph.2010.03.015

Aguirre-Lipperheide, M., Estrada-Rodríyuez, F. J., and Evans, L. V. (1995). Facts, problems, and needs in seaweed tissue culture: an appraisal. J. Phycol. 31, 677-688. doi: 10.1111/j.0022-3646.1995.00677

Aida, M., Beis, D., Heidstra, R., Willemsen, V., Blilou, I., Galinha, C., et al. (2004). The PLETHORA genes mediate patterning of the Arabidopsis root stem cell niche. Cell 119, 109-120. doi: 10.1016/j.cell.2004.09.018

Atta, R., Laurens, L., Boucheron-Dubuisson, E., Guivarc'h, A., Carnero, E., Giraudat-Pautot, V., et al. (2009). Pluripotency of Arabidopsis xylem pericycle underlies shoot regeneration from root and hypocotyl explants grown in vitro. Plant J. 57, 626-644. doi: 10.1111/j.1365-313X.2008.03715

Avivi, Y., Morad, V., Ben-Meir, H., Zhao, J., Kashkush, K., Tzfira, T., et al. (2004). Reorganization of specific chromosomal domains and activation of silent genes in plant cells acquiring pluripotentiality. Dev. Dyn. 230, 12-22. doi: 10.1002/dvdy.20006

Bai, B., Su, Y. H., Yuan, J., and Zhang, X. S. (2013). Induction of somatic embryos in Arabidopsis requires local YUCCA expression mediated by the down-regulation of ethylene biosynthesis. Mol. Plant 6, 1247-1260. doi: 10.1093/mp/sss 154

Banks, J. A. (1999). Gametophyte development in ferns. Annu. Rev. Plant Physiol. Plant Mol. Biol. 50, 163-186. doi: 10.1146/annurev.arplant.50.1.163

Banno, H., Ikeda, Y., Niu, Q. W., and Chua, N. H. (2001). Overexpression of Arabidopsis ESR1 induces initiation of shoot regeneration. Plant Cell 13, 2609-2618. doi: 10.1105/tpc.010234

Barrero, M. J., and Izpisua Belmonte, J. C. (2011). Regenerating the epigenome. EMBO Rep. 12, 208-215. doi: 10.1038/embor.2011.10

Bartel, D. P. (2004). MicroRNAs: genomics, biogenesis, mechanism, and function. Cell 116, 281-297. doi: 10.1016/S0092-8674(04)00045-5

Barton, M. K., and Poethig, R. S. (1993). Formation of the shoot apical meristem in Arabidopsis thaliana: an analysis of development in the wild type and in the shoot meristemless mutant. Development 119, 823-831.

Bassuner, B. M., Lam, R., Lukowitz, W., and Yeung, E. C. (2007). Auxin and root initiation in somatic embryos of Arabidopsis. Plant Cell Rep. 26, 1-11. doi: 10.1007/s00299-006-0207-5

Bastedo, D. P., and Marczynski, G. T. (2009). CtrA response regulator binding to the Caulobacter chromosome replication origin is required during nutrient and antibiotic stress as well as during cell cycle progression. Mol. Microbiol. 72, 139-154. doi: 10.1111/j.1365-2958.2009.06630.x

Benkova, E., Michniewicz, M., Sauer, M., Teichmann, T., Seifertova, D., Jurgens, G., et al. (2003). Local, efflux-dependent auxin gradients as a common module for plant organ formation. Cell 115, 591-602. doi: 10.1016/S0092-8674(03)00924-3

Berdasco, M., Alcazar, R., Garcia-Ortiz, M. V., Ballestar, E., Fernandez, A. F., Roldan-Arjona, T., et al. (2008). Promoter DNA hypermethylation and gene repression in undifferentiated Arabidopsis cells. PLOS ONE 3:e3306. doi: 10.1371/journal.pone.0003306

Birnbaum, K. D., and Sanchez Alvarado, A. (2008). Slicing across kingdoms: regeneration in plants and animals. Cell 132, 697-710. doi: 10.1016/j.cell.2008.01.040

Bouchabke-Coussa, O., Obellianne, M., Linderme, D., Montes, E., Maia-Grondard, A., Vilaine, F., et al. (2013). Wuschel overexpression promotes somatic embryogenesis and induces organogenesis in cotton (Gossypiumhirsutum L.) tissues cultured in vitro. Plant Cell Rep. 32, 675-686. doi: 10.1007/s00299-013-1402-9

Boutilier, K., Offringa, R., Sharma, V. K., Kieft, H., Ouellet, T., Zhang, L., et al. (2002). Ectopic expression of BABY BOOM triggers a conversion from vegetative to embryonic growth. Plant Cell 14, 1737-1749. doi: 10.1105/tpc.001941

Bouyer, D., Roudier, F., Heese, M., Andersen, E. D., Gey, D., Nowack, M. K., et al. (2011). Polycomb repressive complex 2 controls the embryo-to-seedling phase transition. PLoS Genet. 7:e1002014. doi: 10.1371/journal.pgen.1002014

Braybrook, S. A., and Harada, J. J. (2008). LECs go crazy in embryo development. Trends Plant Sci. 13, 624-630. doi: 10.1016/j.tplants.2008.09.008 
Brockes, J. P., and Kumar, A. (2002). Plasticity and reprogramming of differentiated cells in amphibian regeneration. Nat. Rev. Mol. Cell Biol. 3, 566-574. doi: 10.1038/nrm881

Callinan, P. A., and Feinberg, A. P. (2006). The emerging science of epigenomics. Hum. Mol. Genet. 1, R95-R101. doi: 10.1093/hmg/ddl095

Cao, R., Wang, L., Wang, H., Xia, L., Erdjument-Bromage, H., Tempst, P., et al. (2002). Role of histone H3 lysine 27 methylation in Polycomb-group silencing. Science 298, 1039-1043. doi: 10.1126/science.1076997

Cary, A. J., Che, P., and Howell, S. H. (2002). Developmental events and shoot apical meristem gene expression patterns during shoot development in Arabidopsis thaliana. Plant J. 32, 867-877. doi: 10.1046/j.1365-313X.2002.01479.x

Casimiro, I., Marchant, A., Bhalerao, R. P., Beeckman, T., Dhooge, S., Swarup, R., et al. (2001). Auxin transport promotes Arabidopsis lateral root initiation. Plant Cell 13, 843-852. doi: 10.1105/tpc.13.4.843

Celenza, J. L. Jr., Grisafi, P. L., and Fink, G. R. (1995). A pathway for lateral root formation in Arabidopsis thaliana. Genes Dev. 9, 2131-2142. doi: 10.1101/gad.9.17.2131

Chanvivattana, Y., Bishopp, A., Schubert, D., Stock, C., Moon, Y. H., Sung, Z. R., et al. (2004). Interaction of Polycomb-group proteins controlling flowering in Arabidopsis. Development 131, 5263-5276. doi: 10.1242/dev.01400

Chatfield, S. P., Capron, R., Severino, A., Penttila, P. A., Alfred, S., Nahal, H., et al. (2013). Incipient stem cell niche conversion in tissue culture: using a systems approach to probe early events in WUSCHEL-dependent conversion of lateral root primordia into shoot meristems. Plant J. 73, 798-813. doi: 10.1111/tpj.12085

Che, P., Lall, S., and Howell, S. H. (2007). Developmental steps in acquiring competence for shoot development in Arabidopsis tissue culture. Planta 226, 1183-1194. doi: 10.1007/s00425-007-0565-4

Chen, C. J., Liu, Q., Zhang, Y. C., Qu, L. H., Chen, Y. Q., and Gautheret, D. (2011). Genome-wide discovery and analysis of microRNAs and other small RNAs from rice embryogenic callus. RNA Biol. 8, 538-547. doi: 10.4161/rna.8.3. 15199

Chen, J. J., Zhang, J., and He, X. Q. (2013). Tissue regeneration after bark girdling: an ideal research tool to investigate plant vascular development and regeneration. Physiol. Plant. doi: 10.1111/ppl.12112. [Epub ahead of print].

Cheng, Z. J., Wang, L., Sun, W., Zhang, Y., Zhou, C., Su, Y. H., et al. (2013). Pattern of auxin and cytokinin responses for shoot meristem induction results from the regulation of cytokinin biosynthesis by AUXIN RESPONSE FACTOR3. Plant Physiol. 161, 240-251. doi: 10.1104/pp.112.203166

Christianson, M. L., and Warnick, D. A. (1983). Competence and determination in the process of in vitro shoot organogenesis. Dev. Biol. 95, 288-293. doi: 10.1016/0012-1606(83)90029-5

Czermin, B., Melfi, R., McCabe, D., Seitz, V., Imhof, A., and Pirrotta, V. (2002). Drosophila enhancer of Zeste/ESC complexes have a histone H3 methyltransferase activity that marks chromosomal polycomb sites. Cell 111, 185-196. doi: 10.1016/S0092-8674(02)00975-3

Daimon, Y., Takabe, K., and Tasaka, M. (2003). The CUP-SHAPED COTYLEDON genes promote adventitious shoot formation on calli. Plant Cell Physiol. 44, 113-121. doi: 10.1093/pcp/pcg038

Domian, I. J., Quon, K. C., and Shapiro, L. (1997). Cell type-specific phosphorylation and proteolysis of a transcriptional regulator controls the G1-to-S transition in a bacterial cell cycle. Cell 90, 415-424. doi: 10.1016/S00928674(00)80502-4

Donovan, P. J., and Gearhart, J. (2001). The end of the beginning for pluripotent stem cells. Nature 414, 92-97. doi: 10.1038/35102154

Duckworth, A. R., Samples, G. A., Wright, A. E., and Pomponi, S. A. (2003). In vitro culture of the tropical sponge Axinellacorrugata (Demospongiae): effect of food cell concentration on growth, clearance rate, and biosynthesis of stevensine. Mar. Biotechnol. 5, 519-527. doi: 10.1007/s10126-002-0111-0

El Ouakfaoui, S., Schnell, J., Abdeen, A., Colville, A., Labbe, H., Han, S., et al. (2010). Control of somatic embryogenesis and embryo development by AP2 transcription factors. Plant Mol. Biol. 74, 313-326. doi: 10.1007/s11103-0109674-8

Eshed, Y., Baum, S. F., and Bowman, J. L. (1999). Distinct mechanisms promote polarity establishment in carpels of Arabidopsis. Cell 99, 199-209. doi: 10.1016/S0092-8674(00)81651-7

Fan, M., Xu, C., Xu, K., and Hu, Y. (2012). LATERAL ORGAN BOUNDARIES DOMAIN transcription factors direct callus formation in Arabidopsis regeneration. Cell Res. 22, 1169-1180. doi: 10.1038/cr.2012.63
Ferna'ndez H., Bertrand A., and Sa'nchez-Tame's, R. (1997). Plantlet regeneration in Aspleniumnidus L. and Pterisensiformis L. by homogenization of BA treated rhizomes. Sci. Hortic. 68, 243-247. doi: 10.1016/S0304-4238(96)00986-7

Ferna'ndez H., Bertrand A. M., and Sa'nchez-Tame's, R. (1993). In vitro regeneration of Asplenium nidus L. from gametophytic and sporophytic tissue. Sci. Hortic. 56, 71-77. doi: 10.1016/0304-4238(93)90103-W

Francis, N. J., and Kingston, R. E. (2001). Mechanisms of transcriptional memory. Nat. Rev. Mol. Cell Biol. 2, 409-421. doi: 10.1038/35073039

Furuta, K., Kubo, M., Sano, K., Demura, T., Fukuda, H., and Liu, Y.-G. (2011). The CKH2/PKL chromatin remodeling factor negatively regulates cytokinin responses in arabidopsis calli. Plant Cell Physiol. 52, 618-628. doi: $10.1093 / \mathrm{pcp} / \mathrm{pcr} 022$

Gaj, M. D., Zhang, S., Harada, J. J., and Lemaux, P. G. (2005). Leafy cotyledon genes are essential for induction of somatic embryogenesis of Arabidopsis. Planta 222, 977-988. doi: 10.1007/s00425-005-0041-y

Gallois, J. L., Nora, F. R., Mizukami, Y., and Sablowski, R. (2004). WUSCHEL induces shoot stem cell activity and developmental plasticity in the root meristem. Genes Dev. 18, 375-380. doi: 10.1101/gad.291204

Gao, X., Nagawa, S., Wang, G., and Yang, Z. (2008). Cell polarity signaling: focus on polar auxin transport. Mol. Plant 1, 899-909. doi: 10.1093/mp/ssn069

Gargioli, C., and Slack, J. M. (2004). Cell lineage tracing during Xenopus tail regeneration. Development 131, 2669-2679. doi: 10.1242/dev.01155

Gierer, A., Berking, S., Bode, H., David, C. N., Flick, K., Hansmann, G., et al. (1972). Regeneration of hydra from reaggregated cells. Nat. New Biol. 239, 98-101. doi: 10.1038/newbio239098a0

Gliwicka, M., Nowak, K., Balazadeh, S., Mueller-Roeber, B., and Gaj, M. D. (2013). Extensive modulation of the transcription factor transcriptome during somatic embryogenesis in Arabidopsis thaliana. PLoS ONE 8:e69261. doi: 10.1371/journal.pone.0069261

Godwin, J. W., Pinto, A. R., and Rosenthal, N. A. (2013). Macrophages are required for adult salamander limb regeneration. Proc. Natl. Acad. Sci. U.S.A. 110, 9415-9420. doi: 10.1073/pnas.1300290110

Goldstein, M. (1973). Regeneration and vegetative propagation of the agarophyte Gracilaria debilis (FORSSKÅL) BØRGESEN (Rhodophyceae). Bot. Mar. 16, 177-243. doi: 10.1515/botm.1973.16.4.226

Gordon, S. P., Heisler, M. G., Reddy, G. V., Ohno, C., Das, P., and Meyerowitz, E. M. (2007). Pattern formation during de novo assembly of the Arabidopsis shoot meristem. Development 134, 3539-3548. doi: 10.1242/dev.010298

Guo, F., Liu, C., Xia, H., Bi, Y., Zhao, C., Zhao, S., et al. (2013). Induced expression of AtLEC1 and AtLEC2 differentially promotes somatic embryogenesis in transgenic tobacco plants. PLoS ONE 8:e71714. doi: 10.1371/journal.pone.0071714

Guzzo, F., Baldan, B., Mariani, P., Schiavo, F. L., and Terzi, M. (1994). Studies on the origin of totipotent cells in explants of Daucuscarota L. J. Exp. Bot. 45, 5. doi: $10.1093 / \mathrm{jxb} / 45.10 .1427$

Halperin, W. (1986). "Attainment and retention of morphogenetic capacity in vitro," in Cell Culture and Somatic Cell Genetics of Plants, Vol. 3, Plant Regeneration and Genetic Variability, ed I. K. Vasil (Orlando, FL: Academic Press, Inc.), 3-47.

Harding, E. W., Tang, W., Nichols, K. W., Fernandez, D. E., and Perry, S. E. (2003). Expression and maintenance of embryogenic potential is enhanced through constitutive expression of AGAMOUS-Like 15. Plant Physiol. 133, 653-663. doi: 10.1104/pp.103.023499

He, C., Chen, X., Huang, H., and Xu, L. (2012). Reprogramming of H3K27me3 is critical for acquisition of pluripotency from cultured Arabidopsis tissues. PLoS Genet. 8:e1002911. doi: 10.1371/journal.pgen.1002911

Hoppe, W. (1988). Growth, regeneration and predation in three species of large coral reef sponges. Mar. Ecol. Prog. 50, 8. doi: 10.3354/meps050117

Huang, W., and Fujita, Y. (1997). Callus induction and thallus regeneration in some species of red algae. Phycol. Res. 45, 105-111. doi: 10.1111/j.14401835.1997.tb00069

Ikeda. Y., Banno, H., Ikeda, Y., Niu, Q. W., Howell, S. H., and Chua, N. H. (2006). The ENHANCER OF SHOOT REGENERATION 2 gene in Arabidopsis regulates CUP-SHAPED COTYLEDON 1 at the transcriptional level and controls cotyledon development. Plant Cell Physiol. 47, 1443-1456. doi: 10.1093/pcp/pcl023

Iwase, A., Mitsuda, N., Koyama, T., Hiratsu, K., Kojima, M., Arai, T., et al. (2011). The AP2/ERF transcription factor WIND1 controls cell dedifferentiation in Arabidopsis. Curr. Biol. 21, 508-514. doi: 10.1016/j.cub.2011.02.020

Jenuwein, T., and Allis, C. D. (2001). Translating the histone code. Science 293, 1074-1080. doi: 10.1126/science.1063127 
Jimenez, V. M., and Bangerth, F. (2001). Hormonal status of maize initial explants and of the embryogenic and non-embryogenic callus cultures derived from them as related to morphogenesis in vitro. Plant Sci. 160, 247-257. doi: 10.1016/S0168-9452(00)00382-4

Jopling, C., Sleep, E., Raya, M., Marti, M., Raya, A., and Izpisua Belmonte, J. C. (2010). Zebrafish heart regeneration occurs by cardiomyocyte dedifferentiation and proliferation. Nature 464, 606-609. doi: 10.1038/nature08899

Jung, J. H., and Park, C. M. (2007). MIR166/165 genes exhibit dynamic expression patterns in regulating shoot apical meristem and floral development in Arabidopsis. Planta 225, 1327-1338. doi: 10.1007/s00425-006-0439-1

Kazmierczak, A. (2003). Induction of cell division and cell expansion at the beginning of GA3-induced precocious antheridia formation in Anemia phyllitidis gametophytes. Plant Sci. 165, 933-939. doi: 10.1016/S0168-9452(03)00217-6

King, R. S., and Newmark, P. A. (2012). The cell biology of regeneration. J. Cell Biol. 196, 553-562. doi: 10.1083/jcb.201105099

Kragl, M., and Tanaka, E. M. (2009). Axolotl (Ambystomamexicanum) limb and tail amputation. Cold Spring Harb. Protoc. 2009:pdb.prot5267. doi: $10.1101 /$ pdb.prot5267

Kuzmichev, A., Nishioka, K., Erdjument-Bromage, H., Tempst, P., and Reinberg, D. (2002). Histone methyltransferase activity associated with a human multiprotein complex containing the enhancer of zeste protein. Genes Dev. 16, 2893-2905. doi: 10.1101/gad.1035902

La Farge, C., Williams, K. H., and England, J. H. (2013). Regeneration of little ice age bryophytes emerging from a polar glacier with implications of totipotency in extreme environments. Proc. Natl. Acad. Sci. U.S.A. 110, 9839-9844. doi: 10.1073/pnas.1304199110

Laplaze, L., Parizot, B., Baker, A., Ricaud, L., Martiniere, A., Auguy, F., et al. (2005). GAL4-GFP enhancer trap lines for genetic manipulation of lateral root development in Arabidopsis thaliana. J. Exp. Bot. 56, 2433-2442. doi: 10.1093/jxb/eri236

Legendre, M., and Gautheret, D. (2003). Sequence determinants in human polyadenylation site selection. BMC Genomics 4:7. doi: 10.1186/1471-2164-4-7

Lenhoff, S. G., and Lenhoff, H. M. (1986). Hydra and the Birth of Experimental Biology: Abraham Trembley's Memoirs Concerning the Natural History of a Type of Freshwater Polyp with Arms Shaped like Horns. Pacific Grove, CA: The Boxwood Press, 192.

Li, W., Liu, H., Cheng, Z. J., Su, Y. H., Han, H. N., Zhang, Y., et al. (2011). DNA methylation and histone modifications regulate de novo shoot regeneration in Arabidopsis by modulating WUSCHEL expression and auxin signaling. PLoS Genet. 7:e1002243. doi: 10.1371/journal.pgen.1002243

Liu, C., Xu, Z., and Chua, N. H. (1993). Auxin polar transport is essential for the establishment of bilateral symmetry during early plant embryogenesis. Plant Cell 5, 621-630. doi: 10.1105/tpc.5.6.621

Liu, P. P., Montgomery, T. A., Fahlgren, N., Kasschau, K. D., Nonogaki, H., and Carrington, J. C. (2007). Repression of AUXIN RESPONSE FACTOR10 by microRNA160 is critical for seed germination and post-germination stages. Plant J. 52, 133-146. doi: 10.1111/j.1365-313X.2007.03218.x

Liu, Z., Xin, W., Ji, D., Wang, L., Li, J., and Xiang, F. (2013). GUS activity for miR165a/166b, REV, and WUS/CLV3 in in vitro direct Arabidopsis thaliana shoot regeneration. Protoplasma 250, 1213-1218. doi: 10.1007/s00709-0130503-1

Luo, Y. C., Zhou, H., Li, Y., Chen, J. Y., Yang, J. H., Chen, Y. Q., et al. (2006). Rice embryogenic calli express a unique set of microRNAs, suggesting regulatory roles of microRNAs in plant post-embryogenic development. FEBS Lett. 580, 5111-5116. doi: 10.1016/j.febslet.2006.08.046

Lusser, A., Kolle, D., and Loidl, P. (2001). Histone acetylation: lessons from the plant kingdom. Trends Plant Sci. 6, 59-65. doi: 10.1016/S1360-1385(00)01839-2

Mandoli, D. F. (1998). ELABORATION OF BODY PLAN AND PHASE CHANGE DURING DEVELOPMENT OF ACETABULARIA: how is the complex architecture of a giant unicell built? Annu. Rev. Plant Physiol. Plant Mol. Biol. 49, 173-198. doi: 10.1146/annurev.arplant.49.1.173

Matsuo, N., Makino, M., and Banno, H. (2011). Arabidopsis ENHANCER OF SHOOT REGENERATION (ESR)1 and ESR2 regulate in vitro shoot regeneration and their expressions are differentially regulated. Plant Sci. 1811, 39-46. doi: 10.1016/j.plantsci.2011.03.007

Meinke, D. W. (1991). Perspectives on genetic analysis of plant embryogenesis. Plant Cell 3, 857-866. doi: 10.1105/tpc.3.9.857

Menendez, V., Revilla, M. A., Fal., M. A., and Ferna'ndez, H. (2009). The effect of cytokinins on growth and sexual organ development in the gametophyte of Blechnumspicant L. Plant Cell Tissue Organ Cult. 96, 245-250. doi: 10.1007/s11240-008-9481-y

Mordhorst, A. P., Hartog, M. V., El Tamer, M. K., Laux, T., and De Vries, S. C. (2002). Somatic embryogenesis from Arabidopsis shoot apical meristem mutants. Planta 214, 829-836. doi: 10.1007/s00425-001-0700-6

Motte, H., Vereecke, D., Geelen, D., and Werbrouck, S. (2013). The molecular path to in vitro shoot regeneration. Biotechnol. Adv. 32, 107-121. doi: 10.1016/j.biotechadv.2013.12.002

Muday, G. K., Rahman, A., and Binder, B. M. (2012). Auxin and ethylene: collaborators or competitors? Trends Plant Sci. 17, 181-195. doi: 10.1016/j.tplants.2012.02.001

Muller, J., Hart, C. M., Francis, N. J., Vargas, M. L., Sengupta, A., Wild, B., et al. (2002). Histone methyltransferase activity of a Drosophila polycomb group repressor complex. Cell 111, 197-208. doi: 10.1016/S0092-8674(02)00976-5

Noda, K. (1971). Reconstitution of dissociated cells of hydra. Zool. Mag. 80, 27-31.

Ogas, J., Cheng, J. C., Sung, Z. R., and Somerville, C. (1997). Cellular differentiation regulated by gibberellin in the Arabidopsis thaliana pickle mutant. Science 277, 91-94. doi: 10.1126/science.277.5322.91

Ogas, J., Kaufmann, S., Henderson, J., and Somerville, C. (1999). PICKLE is a CHD3 chromatin-remodeling factor that regulates the transition from embryonic to vegetative development in Arabidopsis. Proc. Natl. Acad. Sci. U.S.A. 96, 13839-13844. doi: 10.1073/pnas.96.24.13839

Pang, Y., Zhang, J., Cao, J., Yin, S. Y., He, X. Q., and Cui, K. M. (2008). Phloem transdifferentiation from immature xylem cells during bark regeneration after girdling in Eucommiaulmoides oliv. J. Exp. Bot. 59, 1341-1351. doi: 10.1093/jxb/ern041

Peaucelle, A., Morin, H., Traas, J., and Laufs, P. (2007). Plants expressing a miR164resistant CUC2 gene reveal the importance of post-meristematic maintenance of phyllotaxy in Arabidopsis. Development 134, 1045-1050. doi: 10.1242/dev.02774

Pillon, E., Terzi, M., Baldan, B., Mariani, P., and Lo Schiavo, F. L. (1996). A protocol for obtaining embryogenic cell lines from Arabidopsis. Plant J. 9, 573-577. doi: 10.1046/j.1365-313X.1996.09040573.x

Qiao, M., Zhao, Z., Song, Y., Liu, Z., Cao, L., Yu, Y., et al. (2012). Proper regeneration from in vitro cultured Arabidopsis thaliana requires the microRNA-directed action of an auxin response factor. Plant J. 71, 14-22. doi: 10.1111/j.1365313X.2012.04944.x

Quon, K. C., Yang, B., Domian, I. J., Shapiro, L., and Marczynski, G. T. (1998). Negative control of bacterial DNA replication by a cell cycle regulatory protein that binds at the chromosome origin. Proc. Natl. Acad. Sci. U.S.A. 95, 120-125. doi: 10.1073/pnas.95.1.120

Reinhardt, D., Frenz, M., Mandel, T., and Kuhlemeier, C. (2003). Microsurgical and laser ablation analysis of interactions between the zones and layers of the tomato shoot apical meristem. Development 130, 4073-4083. doi: 10.1242/dev.00596

Reynolds, T. L. (1997). Pollen embryogenesis. Plant Mol. Biol. 33, 1-10. doi: 10.1023/A:1005748614261

Richards, E. J., and Elgin, S. C. (2002). Epigenetic codes for heterochromatin formation and silencing: rounding up the usual suspects. Cell 108, 489-500. doi: 10.1016/S0092-8674(02)00644-X

Sandoval-Guzman, T., Wang, H., Khattak, S., Schuez, M., Roensch, K., Nacu, E., et al. (2013). Fundamental differences in dedifferentiation and stem cell recruitment during skeletal muscle regeneration in two salamander species. Cell Stem Cell 14, 174-187. doi: 10.1016/j.stem.2013.11.007

Santos-Mendoza, M., Dubreucq, B., Miquel, M., Caboche, M., and Lepiniec, L. (2005). LEAFY COTYLEDON 2 activation is sufficient to trigger the accumulation of oil and seed specific mRNAs in Arabidopsis leaves. FEBS Lett. 579, 4666-4670. doi: 10.1016/j.febslet.2005.07.037

Saurin, A. J., Shao, Z., Erdjument-Bromage, H., Tempst, P., and Kingston, R. E. (2001). A Drosophila polycomb group complex includes Zeste and dTAFII proteins. Nature 412, 655-660. doi: 10.1038/35088096

Schoof, H., Lenhard, M., Haecker, A., Mayer, K. F., Jurgens, G., and Laux, T. (2000). The stem cell population of Arabidopsis shoot meristems in maintained by a regulatory loop between the CLAVATA and WUSCHEL genes. Cell 100, 635-644. doi: 10.1016/S0092-8674(00)80700-X

Schuettengruber, B., and Cavalli, G. (2009). Recruitment of polycomb group complexes and their role in the dynamic regulation of cell fate choice. Development 136, 3531-3542. doi: 10.1242/dev.033902

Segui-Simarro, J. M., Corral-Martinez, P., Parra-Vega, V., and Gonzalez-Garcia, B. (2011). Androgenesis in recalcitrant solanaceous crops. Plant Cell Rep. 30, 765-778. doi: 10.1007/s00299-010-0984-8 
Sena, G., Birnbaum, K. D. (2010). Built to rebuild: in search of organizing principles in plant regeneration. Curr. Opin. Genet. Dev. 20, 460-465. doi: 10.1016/j.gde.2010.04.011

Sena, G., Wang, X., Liu, H. Y., Hofhuis, H., and Birnbaum, K. D. (2009). Organ regeneration does not require a functional stem cell niche in plants. Nature 457 , 1150-1153. doi: 10.1038/nature07597

Skoog, F. (1950). Chemical control of growth and organ formation in plant tissues. Annee Biol. 54, 545-562.

Skoog, F., and Miller, C. O. (1957). Chemical regulation of growth and organ formation in plant tissues cultured in vitro. Symp. Soc. Exp. Biol. 11, 118-130.

Somer, M., Arbesu' R., Mene'ndez, V., Revilla, M. A., and Ferna'ndez, H. (2010). Sporophytes induction studies in ferns in vitro. Euphytica 171, 203-210. doi: 10.1007/s10681-009-0018-1

Soriano, M., Li, H., and Boutilier, K. (2013). Microspore embryogenesis: establishment of embryo identity and pattern in culture. Plant Reprod. 26, 181-196. doi: 10.1007/s00497-013-0226-7

Su, Y. H., Zhao, X. Y., Liu, Y. B., Zhang, C. L., O’Neill, S. D., and Zhang, X. S. (2009). Auxin-induced WUS expression is essential for embryonic stem cell renewal during somatic embryogenesis in Arabidopsis. Plant J. 59, 448-460. doi: 10.1111/j.1365-313X.2009.03880.x

Sugimoto, K., Gordon, S. P., and Meyerowitz, E. M. (2011). Regeneration in plants and animals: dedifferentiation, transdifferentiation, or just differentiation? Trends Cell Biol. 21, 212-218. doi: 10.1016/j.tcb.2010.12.004

Sugimoto, K., Jiao, Y., and Meyerowitz, E. M. (2010). Arabidopsis regeneration from multiple tissues occurs via a root development pathway. Dev. Cell 18, 463-471. doi: 10.1016/j.devcel.2010.02.004

Sugiyama, M. (2000). Genetic analysis of plant morphogenesis in vitro. Int. Rev. Cytol. 196, 67-84. doi: 10.1016/S0074-7696(00)96002-9

Takahashi, K., and Yamanaka, S. (2006). Induction of pluripotent stem cells from mouse embryonic and adult fibroblast cultures by defined factors. Cell 126, 663-676. doi: 10.1016/j.cell.2006.07.024

Tsuchisaka, A., and Theologis, A. (2004). Unique and overlapping expression patterns among the Arabidopsis 1-amino-cyclopropane-1-carboxylate synthase gene family members. Plant Physiol. 136, 2982-3000. doi: 10.1104/pp.104.049999

Tsuwamoto, R., Yokoi, S., and Takahata, Y. (2010). Arabidopsis EMBRYOMAKER encoding an AP2 domain transcription factor plays a key role in developmental change from vegetative to embryonic phase. Plant Mol. Biol. 73, 481-492. doi: 10.1007/s11103-010-9634-3

Valvekens, D., Montagu, M. V., and Van Lijsebettens, M. (1988). Agrobacterium tumefaciens-mediated transformation of Arabidopsis thaliana root explants by using kanamycin selection. Proc. Natl. Acad. Sci. U.S.A. 85, 5536-5540. doi: 10.1073/pnas.85.15.5536

Wade, P. A., Pruss, D., and Wolffe, A. P. (1997). Histone acetylation: chromatin in action. Trends Biochem. Sci. 22, 128-132. doi: 10.1016/S0968-0004(97)01016-5

Wang, J., Karra, R., Dickson, A. L., and Poss, K. D. (2013). Fibronectin is deposited by injury-activated epicardial cells and is necessary for zebrafish heart regeneration. Dev. Biol. 382, 427-435. doi: 10.1016/j.ydbio.2013.08.012

Wang, M., Qi, X., Zhao, S., Zhang, S., and Lu, M. Z. (2009). Dynamic changes in transcripts during regeneration of the secondary vascular system in Populustomentosa Carr. revealed by cDNA microarrays. BMC Genomics 10:215. doi: $10.1186 / 1471-2164-10-215$
Weigel, D., and Glazebrook, J. (2002). Arabidopsis: A Laboratory Manual. New York, NY: Cold Spring Harbor Laboratory Press.

Wojcikowska, B., Jaskola, K., Gasiorek, P., Meus, M., Nowak, K., and Gaj, M. D. (2013). LEAFY COTYLEDON2 (LEC2) promotes embryogenic induction in somatic tissues of Arabidopsis, via YUCCA-mediated auxin biosynthesis. Planta 238, 425-440. doi: 10.1007/s00425-013-1892-2

Wong, R. C., Donovan, P. J., and Pebay, A. (2011). Molecular mechanism involved in the maintenance of pluripotent stem cells. J. Stem Cells 6, 213-232.

Xu, J., Hofhuis, H., Heidstra, R., Sauer, M., Friml, J., and Scheres, B. (2006). A molecular framework for plant regeneration. Science 311, 385-388. doi: $10.1126 /$ science. 1121790

$\mathrm{Xu}$, L., and Huang, H. (2014). Genetic and epigenetic controls of plant regeneration. Curr. Top. Dev. Biol. 108, 1-33. doi: 10.1016/B978-0-12-391498-9.00009-7

Yoshida, N., Yanai, Y., Chen, L., Kato, Y., Hiratsuka, J., Miwa, T., et al. (2001). EMBRYONIC FLOWER2, a novel polycomb group protein homolog, mediates shoot development and flowering in Arabidopsis. Plant Cell 13, 2471-2481. doi: 10.1105/tpc.010227

Yu, J., Vodyanik, M. A., Smuga-Otto, K., Antosiewicz-Bourget, J., Frane, J. L., Tian, S., et al. (2007). Induced pluripotent stem cell lines derived from human somatic cells. Science 318, 1917-1920. doi: 10.1126/science.1151526

Zhang, H., Bishop, B., Ringenberg, W., Muir, W. M., and Ogas, J. (2012). The CHD3 remodeler PICKLE associates with genes enriched for trimethylation of histone H3 lysine 27. Plant Physiol. 159, 418-432. doi: 10.1104/pp.112.194878

Zhang, J., Gao, G., Chen, J. J., Taylor, G., Cui, K. M., and He, X. Q. (2011). Molecular features of secondary vascular tissue regeneration after bark girdling in Populus. New Phytol. 192, 869-884. doi: 10.1111/j.1469-8137.2011.03855.x

Zhang, Y., and Reinberg, D. (2001). Transcription regulation by histone methylation: interplay between different covalent modifications of the core histone tails. Genes Dev. 15, 2343-2360. doi: 10.1101/gad.927301

Zimmerman, J. L. (1993). Somatic embryogenesis: a model for early development in higher plants. Plant Cell 5, 1411-1423. doi: 10.1105/tpc.5.10.1411

Zuo, J., Niu, Q. W., Frugis, G., and Chua, N. H. (2002). The WUSCHEL gene promotes vegetative-to-embryonic transition in Arabidopsis. Plant J. 30, 349-359. doi: 10.1046/j.1365-313X.2002.01289.x

Conflict of Interest Statement: The authors declare that the research was conducted in the absence of any commercial or financial relationships that could be construed as a potential conflict of interest.

Received: 05 February 2014; accepted: 25 March 2014; published online: 11 April 2014. Citation: Pulianmackal AJ, Kareem AVK, Durgaprasad K, Trivedi ZB and Prasad K (2014) Competence and regulatory interactions during regeneration in plants. Front. Plant Sci. 5:142. doi: 10.3389/fpls.2014.00142

This article was submitted to Plant Genetics and Genomics, a section of the journal Frontiers in Plant Science.

Copyright (c) 2014 Pulianmackal, Kareem, Durgaprasad, Trivedi and Prasad. This is an open-access article distributed under the terms of the Creative Commons Attribution License (CC BY). The use, distribution or reproduction in other forums is permitted, provided the original author(s) or licensor are credited and that the original publication in this journal is cited, in accordance with accepted academic practice. No use, distribution or reproduction is permitted which does not comply with these terms. 